\title{
Global and regional ecological boundaries drive abrupt changes in
}

\section{avian frugivory interactions}

Authors: Lucas P. Martins ${ }^{1 *}$, Daniel B. Stouffer ${ }^{1}$, Pedro G. Blendinger ${ }^{2,3}$, Katrin Böhning-Gaese ${ }^{4}$, Galo Buitrón-Jurado ${ }^{5,6}$, Marta Correia ${ }^{7}$, José Miguel Costa ${ }^{7}$, D. Matthias Dehling ${ }^{8}$, Camila I. Donatti ${ }^{9,10}$, Carine Emer ${ }^{11,12}$, Mauro Galetti ${ }^{12,13}$, Ruben Heleno $^{7}$, Pedro Jordano ${ }^{14,15}$, Ícaro Menezes ${ }^{16}$, José Carlos Morante-Filho ${ }^{16}$, Marcia C. Muñoz ${ }^{17}$, Eike Lena Neuschulz ${ }^{4}$, Marco Aurélio Pizo ${ }^{12}$, Marta Quitián ${ }^{18}$, Roman A. Ruggera $^{19}$, Francisco Saavedra ${ }^{20}$, Vinicio Santillán ${ }^{21}$, Matthias Schleuning ${ }^{4}$, Luís Pascoal da Silva ${ }^{22}$, Fernanda Ribeiro da Silva ${ }^{23}$, Sérgio Timóteo ${ }^{7}$, Anna Traveset $^{24}$, Maximilian G. R. Vollstädt ${ }^{25}$, Jason M. Tylianakis ${ }^{1 *}$

\section{Affiliations:}

${ }^{1}$ School of Biological Sciences, University of Canterbury; Private bag 4800,

Christchurch 8140, Aotearoa New Zealand.

${ }^{2}$ Instituto de Ecología Regional, Universidad Nacional de Tucumán and CONICET; CC 34, 4107 Tucumán, Argentina.

${ }^{3}$ Facultad de Ciencias Naturales e Instituto Miguel Lillo, Universidad Nacional de Tucumán; Miguel Lillo 2005, 4000 Tucumán, Argentina.

${ }^{4}$ Senckenberg Biodiversity and Climate Research Centre; Senckenberganlage 25, 60325 Frankfurt am Main, Germany.

${ }^{5}$ Laboratorio de Biología de Organismos, Centro de Ecología, Instituto Venezolano de Investigaciones Científicas; Km 11 Carretera Panamericana, Apartado 2032, Caracas, 1020-A, Miranda, Venezuela.

${ }^{6}$ Universidad Estatal Amazónica-Sede Zamora Chinchipe; Calle Luis Imaicela entre Azuay y Rene Ulloa, El Pangui, Zamora Chinchipe, Ecuador. 
${ }^{7}$ Centre for Functional Ecology, Department of Life Sciences, University of Coimbra;

Calçada Martim de Freitas, 3000-456 Coimbra, Portugal.

${ }^{8}$ Swiss Federal Research Institute WSL; Zürcherstrasse 111, 8903 Birmensdorf,

Switzerland.

${ }^{9}$ Conservation International; 2011 Crystal Dr. Suite 600, Arlington VA 22202, USA.

${ }^{10}$ Department of Biological Sciences, Northern Arizona University; 617 S. Beaver St., Flagstaff AZ 86011-5640, USA.

${ }^{11}$ Department of Botany, Federal University of Pernambuco; Av. Prof. Moraes Rego, 1235 - Cidade Universitária, 50670-901 Recife - PE, Brazil.

${ }^{12}$ Department of Biodiversity, São Paulo State University - UNESP;

Rio Claro, SP, Brazil.

${ }^{13}$ Department of Biology, University of Miami; Coral Gables, FL 33146, USA.

${ }^{14}$ Estación Biológica de Doñana, CSIC; av. Americo Vespucio 26, 41092 Sevilla, Spain.

${ }^{15}$ Departamento de Biología Vegetal y Ecología, Universidad de Sevilla, Sevilla, Spain.

${ }^{16}$ Applied Conservation Ecology Lab, Santa Cruz State University; Rodovia Ilhéus-

Itabuna, km 16, Salobrinho, Ilhéus, Bahia 45662-000, Brazil.

${ }^{17}$ Programa de Biología, Universidad de La Salle; Carrera 2 \# 10-70, Bogotá, Colombia. ${ }^{18}$ Systematic Zoology Laboratory, Tokyo Metropolitan University TMU; Tokyo, 1-1

Minami-Osawa, Hachioji-shi, Tokyo 192-0397, Japan.

${ }^{19}$ Instituto de Ecorregiones Andinas (Consejo Nacional de Investigaciones Científicas y Técnicas - Universidad Nacional de Jujuy); Canónigo Gorriti 237, Y4600 San Salvador de Jujuy, Jujuy, Argentina.

${ }^{20}$ Instituto de Ecología, Facultad de Ciencias Puras y Naturales, Universidad Mayor de San Andrés; La Paz, Bolivia. 
${ }^{21}$ Centro de Investigación, Innovación y Transferencia de Tecnología (CIITT),

Universidad Católica de Cuenca; Av. de las Americas, Cuenca, Ecuador.

${ }^{22}$ CIBIO-InBIO, Research Center in Biodiversity and Genetic Resources, University of

Porto; 4485-661 Vairão, Portugal.

${ }^{23}$ Laboratory of Human Ecology and Ethnobotany, Department of Ecology and

Zoology, Federal University of Santa Catarina, UFSC; Campus Trindade, s/n,

Florianópolis/SC 88010-970, Brazil.

${ }^{24}$ Instituto Mediterráneo de Estudios Avanzados (CSIC-UIB); Miquel Marqués 21,

07190 Esporles, Mallorca, Balearic Islands, Spain.

${ }^{25}$ Center for Macroecology, Evolution and Climate, GLOBE Institute, University of

Copenhagen; Universitetsparken 15, 2100 Copenhagen Ø, Denmark.

*Corresponding authors. Email: martinslucas.p@gmail.com (L.P.M);

jason.tylianakis@canterbury.ac.nz (J.M.T) 
Abstract: Species interactions can propagate disturbances across space, though ecological and biogeographic boundaries may limit this spread. We tested whether largescale ecological boundaries (ecoregions and biomes) and human disturbance gradients increase dissimilarity among ecological networks, while accounting for background spatial and elevational effects and differences in network sampling. We assessed network dissimilarity patterns over a broad spatial scale, using 196 quantitative avian frugivory networks (encompassing 1,496 plant and 1,003 bird species) distributed across 67 ecoregions and 11 biomes. Dissimilarity in species and interactions, but not in network structure, increased significantly across ecoregion and biome boundaries and along human disturbance gradients. Our findings suggest that ecological boundaries contribute to maintaining the world's biodiversity of interactions and mitigating the propagation of disturbances at large spatial scales.

One-Sentence Summary: Ecoregions and biomes delineate the large-scale distribution of plant-frugivore interactions.

\section{Main text:}

Abiotic gradients underlie the existence of a wide array of natural ecosystems, which are the cornerstone of biological diversity on Earth $(1,2)$. Ecoregion borders delineate regional discontinuities in the environment and in species composition $(3,4)$, whereas biomes mark these 'break points' at a global scale, such that ecoregions are nested within biomes (1, 4 and fig. S1). Accordingly, ecoregion and biome maps have been widely used for delimiting terrestrial ecosystems and guiding conservation planning $(4,5)$, but the question of whether distinct ecoregions truly represent sharp boundaries for species composition across several taxa was only recently answered on a global scale (3). 
There has been growing recognition that interactions among species are critical for biodiversity and ecosystem functioning (6) and an important component of biodiversity in themselves, such that interactions may disappear well before the species involved (7). Species interactions also provide a pathway for the propagation of disturbances via direct and indirect effects, such as secondary extinctions and apparent competition $(8,9)$, potentially connecting species at a global scale. Thus, both natural and human disturbances in local communities of interacting species might reverberate and affect ecosystem functioning at multiple sites $(10,11)$. However, the spread of disturbances may be hindered when interactions are arranged into distinct compartments (12). Despite this importance, we are only beginning to understand whether such discontinuities exist in ecological networks at very large scales $(10,11)$, such as across ecoregions and biomes, potentially acting as a barrier to the global spread of disturbances.

Because species tend to be replaced across ecosystems $(2,3)$ and environmental conditions can favour some types of interactions over others (13), we hypothesize that the large-scale distribution of species interactions is punctuated by ecoregion and biome boundaries. Alternatively, even though at smaller scales habitats may differ in their interactions (14), interactions that occur across habitat boundaries can connect their assemblages, causing multiple habitats to function as a single unit (9). Moreover, ecological boundaries might be further blurred by the processes of species and interaction homogenization, which accompany land-use change and biotic invasion $(10,15)$. Thus, an alternative hypothesis would be that shared interactions and biotic homogenization prevent any sharp discontinuities in interaction composition (i.e., the identity of interactions). Importantly, natural and human-disturbance gradients are juxtaposed with spatial processes that drive gradual changes in species and interaction composition (13). Indeed, distance-decay relationships have been demonstrated across spatial and 
elevational gradients not only for species (16), but also for ecological networks (17-19), and likely result from dispersal limitation and increasing environmental dissimilarity with increasing geographic distance (16).

Here we evaluate whether significant changes in the composition of species, the composition of interactions, and the structure of local networks of avian frugivory are driven by large-scale ecological boundaries (ecoregions and biomes) and human disturbance gradients, while accounting for background spatial and elevational effects. Given known patterns of species turnover across environmental gradients (16), we hypothesize a similar pattern of interaction dissimilarity, which could potentially lead to changes in the whole structure of networks. We focused on frugivory networks because of their importance for seed dispersal (20), promoting species diversity (21) and regenerating degraded ecosystems (22). As such, mapping the large-scale distribution of plant-frugivore interactions will be crucial to ensure ecosystem functioning and resilience in a context of increasing global changes.

To test our hypotheses, we assembled a large-scale database comprising 196 quantitative local networks of avian frugivory (with 9,819 links between 1,496 plant and 1,003 bird species) distributed across 67 ecoregions, 11 biomes, and 6 continents (figs. $\mathrm{S} 1, \mathrm{~S} 2$ and table S1). To ensure that our results would not be driven by taxonomic uncertainty and sampling effects, we standardized the taxonomy of plant and bird species in our networks following a series of steps (figs. S3 to S6) and controlled statistically for network sampling metrics in our analyses [see materials and methods (23)].

We generated several distance matrices $(\mathrm{N} \times \mathrm{N}$, where $\mathrm{N}$ is the number of local networks in our dataset) to be our variables in the statistical models (23). Specifically, we used ecoregion, biome, local human disturbance [measured using the human footprint index (24)], spatial, elevation and sampling-related (i.e., hours, months, years, intensity 
and methods; figs. S7, S8 and table S2) distance matrices as predictor variables, and facets of network dissimilarity as the response variable. We constructed two distinct versions of the ecoregion and biome distance matrices: in the binary version, pairs of networks were given a dissimilarity of zero if they came from localities within the same ecoregion/biome, otherwise one; in the quantitative version, we calculated a continuous measure of environmental distance between the ecoregions and biomes where the networks were located (23). We used three response variables: species turnover $\left(\beta_{\mathrm{S}}\right)$, which estimates the pairwise dissimilarity in species composition between networks (25), interaction dissimilarity $\left(\beta_{\mathrm{WN}}\right)$, which represents the pairwise dissimilarity in the identity of interactions between networks (25), and network structural dissimilarity, which captures differences in the number of links in the networks, their relative weightings, and their arrangement among species. To generate this latter metric, we combined several network descriptors (weighted connectance, weighted nestedness, interaction evenness, PDI and modularity) using Principal Component Analysis (23). To evaluate the effect of each of our predictor distance matrices on our response variables, we employed a combination of Generalized Additive Models and Multiple Regression on Distance Matrices (26). Finally, we explored the unique and shared contributions of our predictor variables to network dissimilarity using deviance partitioning (23).

As expected based on the definition of ecoregions and biomes, the turnover of plant and frugivorous-bird species composition was strongly affected by ecoregion and biome boundaries (tables S4 and S5; fig. S9, A and B). Similarly, there was an overall trend of networks located at different positions along the human disturbance gradient having different species composition (tables S4, S5 and fig. S9C). Despite these effects, spatial distance alone accounted for the greatest proportion of deviance explained in 
species turnover across networks, followed by the shared contribution of spatial distance and ecoregion boundaries (fig. S10).

We found that plant-frugivore interaction dissimilarity increased significantly across ecoregions, biomes, and different levels of human disturbance, even after accounting for the effects of spatial distance, elevational differences, and samplingrelated metrics (Table 1 and table S6). This provides strong support to the hypothesis that large-scale ecological boundaries mark spatially abrupt changes in plant-frugivore interactions (Figs. 1, 2 and fig. S11). Importantly, a great proportion of the deviance explained by biomes was shared with ecoregions (Fig. 3 and fig. S12), which suggests that changes in interaction dissimilarity across biome boundaries mostly reflect the variation occurring at a finer (ecoregion) scale. In fact, crossing an ecoregion boundary induced an average $7 \%$ increase in interaction dissimilarity, while crossing a biome boundary induced only an additional $0.2 \%$ change. As with species, networks located at opposite ends of the human disturbance continuum usually exhibited very different interactions (Fig. 4 and fig. S13).

In addition to the importance of ecological boundaries and human disturbance gradients in driving plant-frugivore interaction dissimilarity, these effects were observed against a background of increasing interaction dissimilarity through space. Indeed, interaction dissimilarity increased sharply until a threshold distance of around 2,500 km between network sites, beyond which few networks shared any interactions and dissimilarity remained close to its peak (Fig. 5 and fig. S14). In the cases where spatially distant networks shared interactions, these typically involved species that had been introduced in at least one location. For instance, the interaction between the Blackbird Turdus merula and the Blackberry Rubus fruticosus was shared between networks located 
more than 18,000 km apart: while both species are native in Europe, they have been introduced to Aotearoa New Zealand.

The shared effect of ecoregion boundaries and spatial distance explained the greatest proportion of the variability in plant-frugivore interaction dissimilarity, followed by the unique contributions of these two variables (Fig. 3). This indicates that gradual increases in interaction dissimilarity over space are made significantly steeper when crossing ecoregion boundaries; this combined effect better describes the variation in plant-frugivore interactions at large spatial scales than any of the other analysed variables.

Despite significant turnover in species and interaction composition, structural dissimilarity of frugivory networks did not change consistently across large-scale ecological boundaries and human disturbance gradients, being only affected by spatial and sampling intensity distances (tables S7 and S8). All the above findings held true when evaluating both the binary and quantitative versions of ecoregion and biome distance matrices (Table 1 and tables S4 to S8). Furthermore, all our main results were robust to different processes of assigning uniqueness to problematic species (i.e., species without a valid epithet) (tables S9 to S33). Finally, most reported patterns were robust to the removal of individual studies from the dataset (figs. S15 and S16; tables S34 and S35).

Our results support the hypothesis that large-scale ecological boundaries drive abrupt changes in species and interaction composition of avian frugivory networks. Specifically, on top of the gradual effect of spatial distance on interaction dissimilarity (whereby networks $>2,500 \mathrm{~km}$ apart had very few interactions in common), transitions across ecoregions and biomes promoted divergence in species interactions. These results show that ecoregions and biomes, classically defined based on environmental conditions and species occurrences $(1,3,4)$, also carry a signature within biotic interactions. This means that species biogeography is matched by a higher-order biogeography of 
interactions. In parallel, human disturbance gradients promoted shifts in species and interaction composition, which might be partly attributed to the filtering of sensitive species and their interactions from disturbed sites $(17,27)$. In fact, while networks from natural ecosystems usually contain interactions between native species, which better reflect natural biogeographic patterns (10) and are more susceptible to human disturbances (27), interactions from high-disturbance regions are generally performed by generalist and introduced species $(17,27,28)$. Nevertheless, we found that the structure of avian frugivory networks was relatively consistent across large-scale environmental gradients. Similar results have been reported at smaller scales (28), indicating that assembly rules may generate common structural patterns in plant-frugivore networks (29) despite the shifts in species and interaction composition that usually accompany environmental changes (13).

Because most of the variation in interaction dissimilarity across biome borders can be explained by ecoregion boundaries, preserving the distinctness of ecoregions $(3,4)$ will likely contribute to maintaining the natural barriers that limit the spread of disturbances across the global network of frugivory. Unfortunately, the unique assemblages that comprise ecoregions have been increasingly threatened by global changes $(4,5)$. Biotic homogenization, in particular, has contributed to blurring biogeographical signatures (10, 15) and the effect of spatial processes on interaction dissimilarity (10). This notion is reinforced by the fact that all long-distance $(>10,000 \mathrm{~km})$ connections (shared interactions) between local networks of frugivory involved at least one region where novel interactions performed by introduced species have largely replaced those performed by native species, such as Aotearoa New Zealand and Hawai'i $(28,30)$. Interestingly, these long-distance connections tend to occur more frequently within than across biomes, despite a greater proportion of network comparisons being cross-biome (fig. S17). This 
indicates that biomes may represent meaningful boundaries not only for species, but also for novel interactions resulting from species introductions around the world (10). Taken together, these results suggest that disturbances in local networks of frugivory are much less likely to impact networks from distant sites or elevations, especially if the networks are located within distinct ecoregions and biomes.

Although species turnover and interaction dissimilarity responded to similar ecological drivers, species might interact differently across environmental gradients not only because of changes in species composition, but also because of partner switching associated with shifts in species abundance (i.e., the probability of random encounters), foraging behaviour and co-evolutionary patterns (13). To evaluate whether interaction rewiring [i.e., the extent to which shared species interact differently (25)] increases across large-scale environmental gradients, we used data limited to pairs of networks sharing plant and bird species $(n=1,314)(23)$. Of these, $93 \%$ had some degree of interaction rewiring, while around $30 \%$ did not have any interaction in common. We found that interaction rewiring increased significantly across human disturbance, spatial, and elevational gradients (table S36), partially explaining why interactions tend to turn over faster than species at large spatial scales (figs. S9D and S14C). Indeed, networks shared considerably more species than interactions (Fig. 1 and fig. S18), reinforcing previous findings that plant and bird species are flexible and tend to switch among their potential partners, even when networks have similar species composition (28). Surprisingly, we did not find an effect of ecoregion boundaries on interaction rewiring, probably because of their collinearity with our other predictor variables (tables S36 and S37).

As with other studies [e.g., $(10,31)]$, our data were not evenly spread across the globe, which likely affected the observed patterns. For instance, around 59\% of our networks were located within a single tropical biome (fig. S2). Because ecoregions tend 
to be more distinct in tropical than in temperate zones (32), the greater number of networks from tropical ecosystems [which also possess most of the world's ecoregions (4)] may have contributed to the strong observed effect of ecoregion boundaries on interaction dissimilarity. Nevertheless, both species richness and the proportion of frugivorous birds reach their peaks in the Tropics (33), suggesting that the distribution of networks in our dataset partially mirrors the global distribution of avian frugivory. Importantly, the extent to which our results apply for other frugivorous taxa (such as mammals and reptiles) and interaction types remains to be investigated. Previous findings, however, indicate that less mobile taxa tend to show a stronger adherence to ecological boundaries (32), a pattern that is likely to be reflected in species interactions.

This work provides evidence that ecological boundaries and human disturbance gradients delineate the large-scale distribution of species and their interactions. Nevertheless, network structure remained consistent across environmental gradients, suggesting that the ecological processes underlying the architecture of frugivory networks may be independent of species and interaction composition. By demonstrating the validity of the ecoregion-based approach $(4,5)$ for species interactions, our results have important implications for maintaining the world's biodiversity of interactions and the myriad ecological functions they provide. 


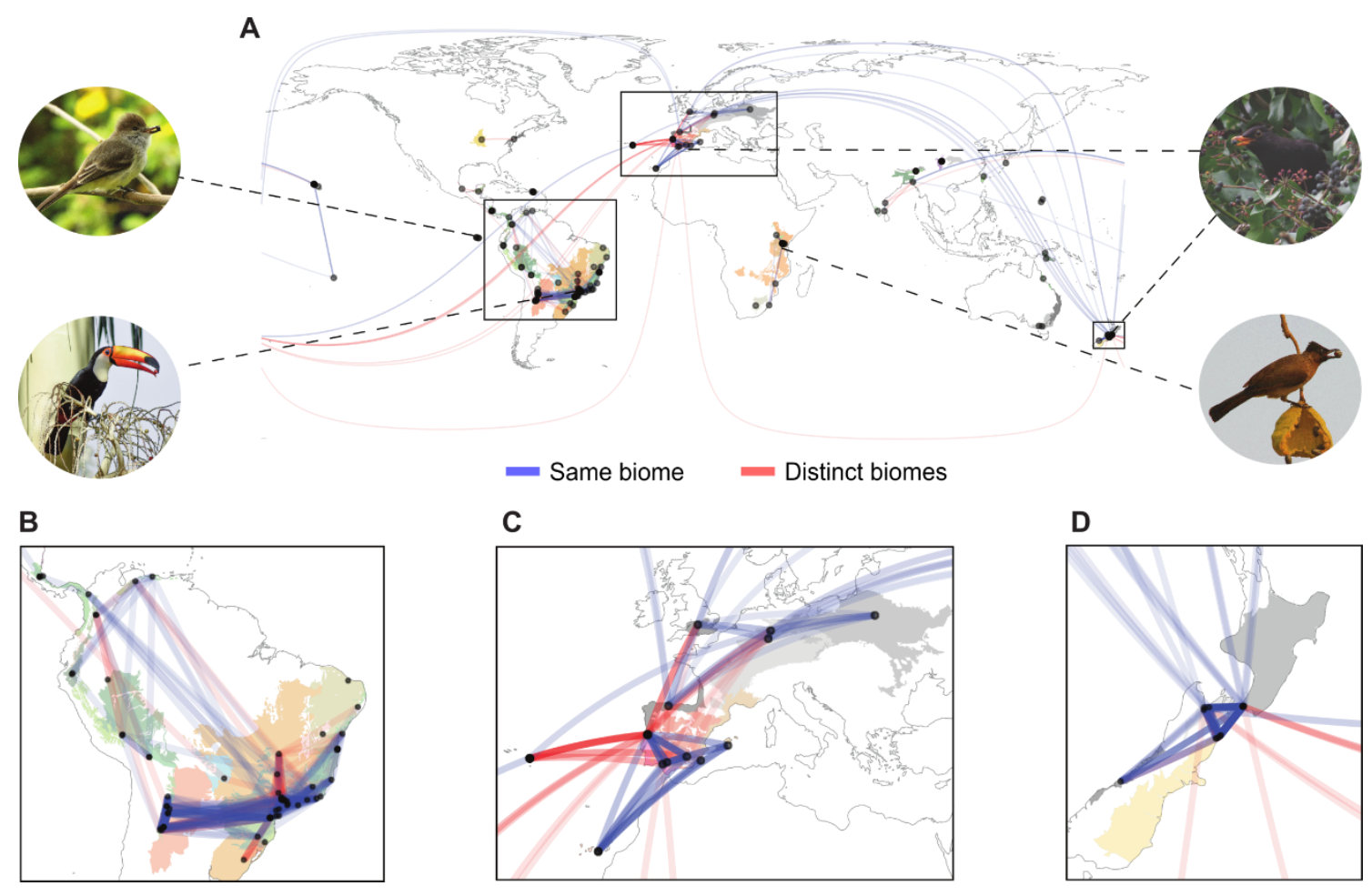

Fig. 1. Plant-frugivore interactions shared among local networks, ecoregions and

biomes. (A) World map with points representing the 196 local avian frugivory networks in our dataset. Colors of shaded areas represent the 67 ecoregions where networks were located, with similar colors indicating ecoregions that belong to the same biome. Lines represent the connections (shared interactions) plotted along the great circle distance between networks, with most of these connections occurring within (blue lines) rather than across (red lines) biomes. Stronger colour tones of lines indicate higher similarity of interactions $\left(1-\beta_{\mathrm{WN}}\right)$ between networks. Connections across continents were mostly attributed to introduced species in one of these regions. Photos show some of the frugivorous birds present in our dataset. Inset maps depict three regions with many networks and connections (especially within biomes). (B) South America. (C) Europe. (D) Aotearoa New Zealand. [Photo credits: R. Heleno (top left and bottom right); R. B. Missano (bottom left); J. M. Costa (top right)]. 

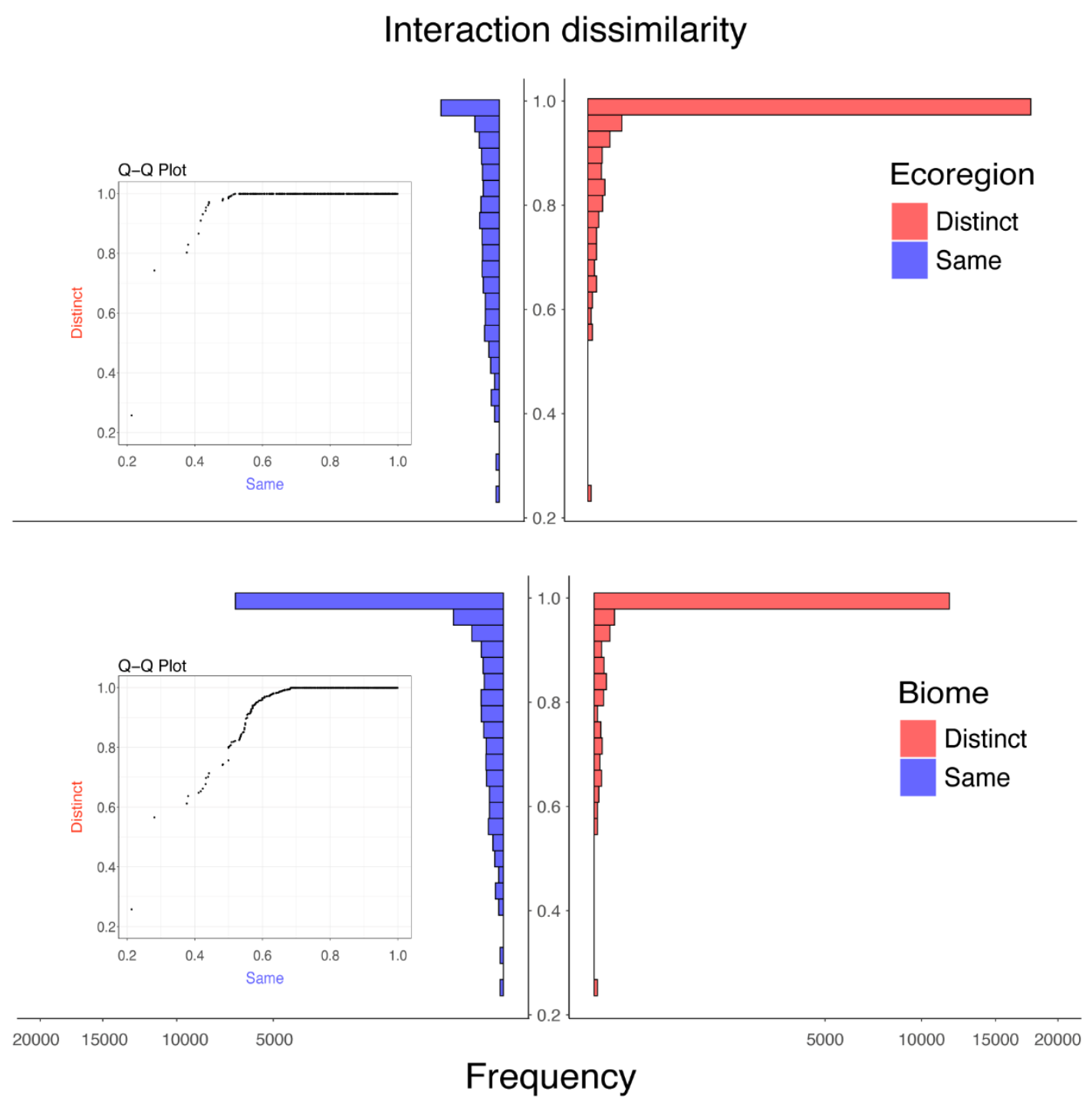

Fig. 2. The effects of ecological boundaries on interaction dissimilarity. Histograms and inset quantile-quantile plots showing differences in the distributions of interaction dissimilarity values between pairs of networks located within ('same') and across ('distinct') ecoregions and biomes. The effects of ecoregion and biome boundaries were significant, even after controlling for the other predictor variables in the model. We square root transformed the $\mathrm{x}$-axis scale to allow a better visualization of the distribution of data points (pairs of networks) with interaction dissimilarity values $<1$. 

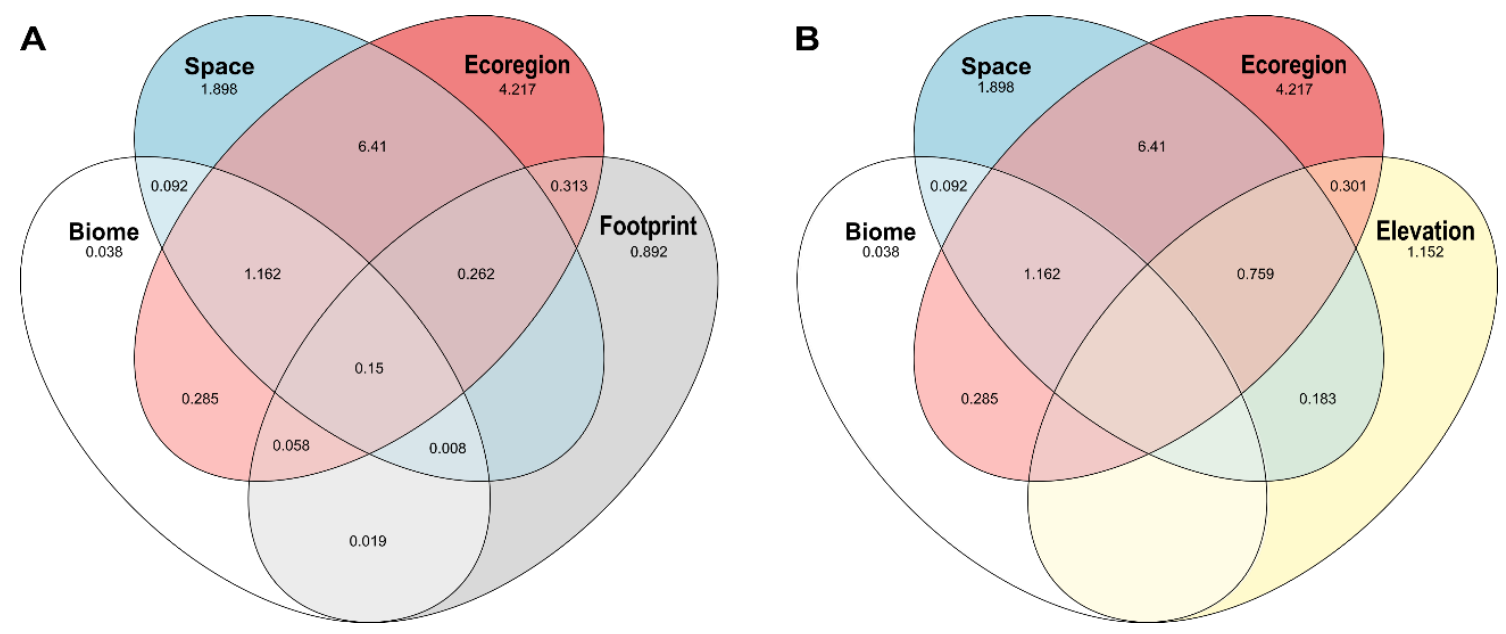

Fig. 3. Venn diagrams showing the relative contributions $(\%)$ of our main predictor variables to explaining the variation in interaction dissimilarity, calculated using deviance partitioning. Overlapping areas represent deviance that is jointly explained by one or more predictor variables. (A) The relative contributions of ecoregions, biomes, spatial distance and human disturbance (i.e., footprint). In (B), we replace human footprint distance with elevational difference; we show these two separate diagrams for visualization purposes, but fig. S12 shows the effect of all our main predictor variables together. Note that we only plot our predictor variables of interest (i.e., not those used for controlling sampling effects). Terms that reduce explanatory power are not shown. 


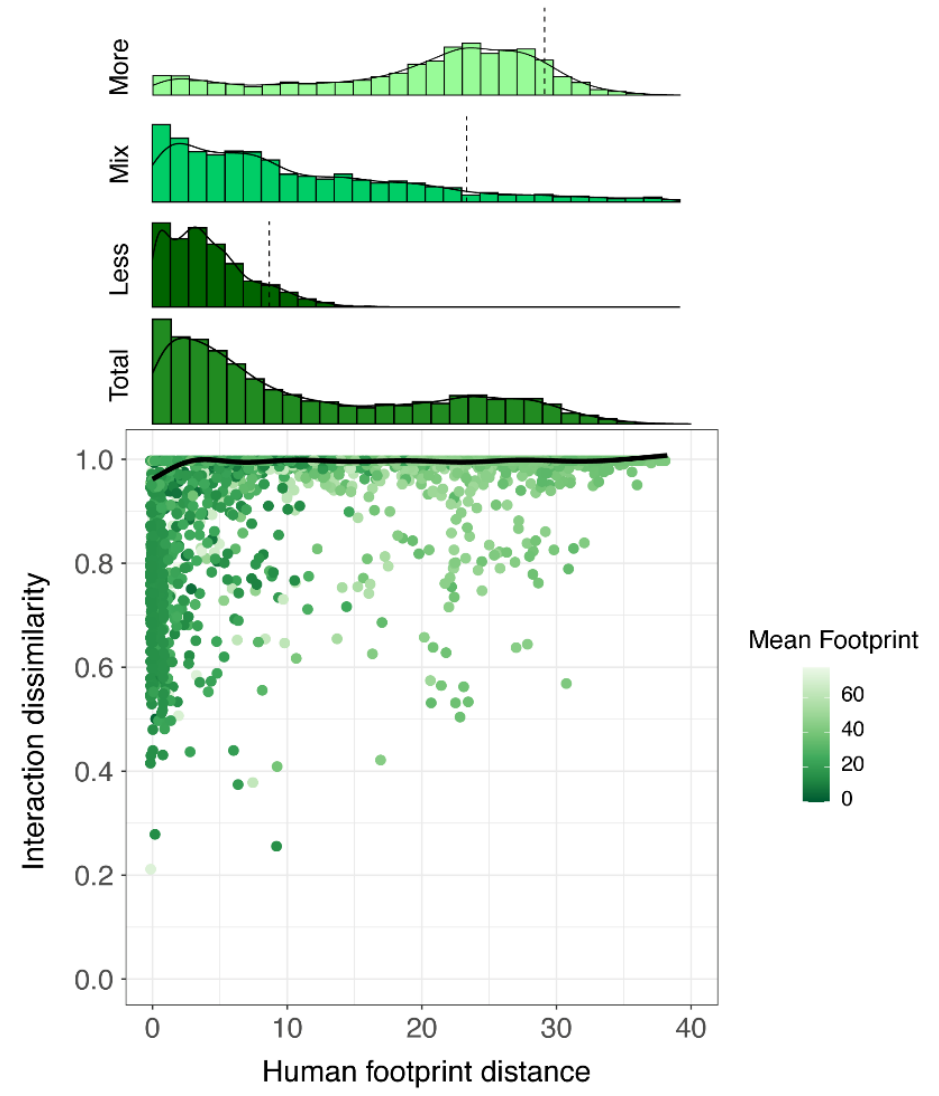

Fig. 4. The effect of human disturbance gradients on interaction dissimilarity. The relationship between human disturbance (i.e., footprint) distance and interaction dissimilarity, with a fitted line obtained from a generalized additive model (GAM) with human footprint distance as the only predictor variable (fig. S13 shows the partial effects plot for the model including all predictors). Each data point (pair of networks) is coloured according to the mean of the human footprint values from the two networks. The histogram above the plot shows the distribution of data points across the human disturbance gradient. We further divided our data into three equal sized groups (top three histograms) based on their mean footprint values: 'Less' disturbed (low mean footprint), 'Mix' (medium mean footprint) and 'More' disturbed (high mean footprint). Dashed lines mark the $90^{\text {th }}$ percentile position in each histogram. Note that data points from less disturbed site pairs are skewed towards low values of human footprint distance, whereas pairs of more disturbed sites also had a larger average distance. 


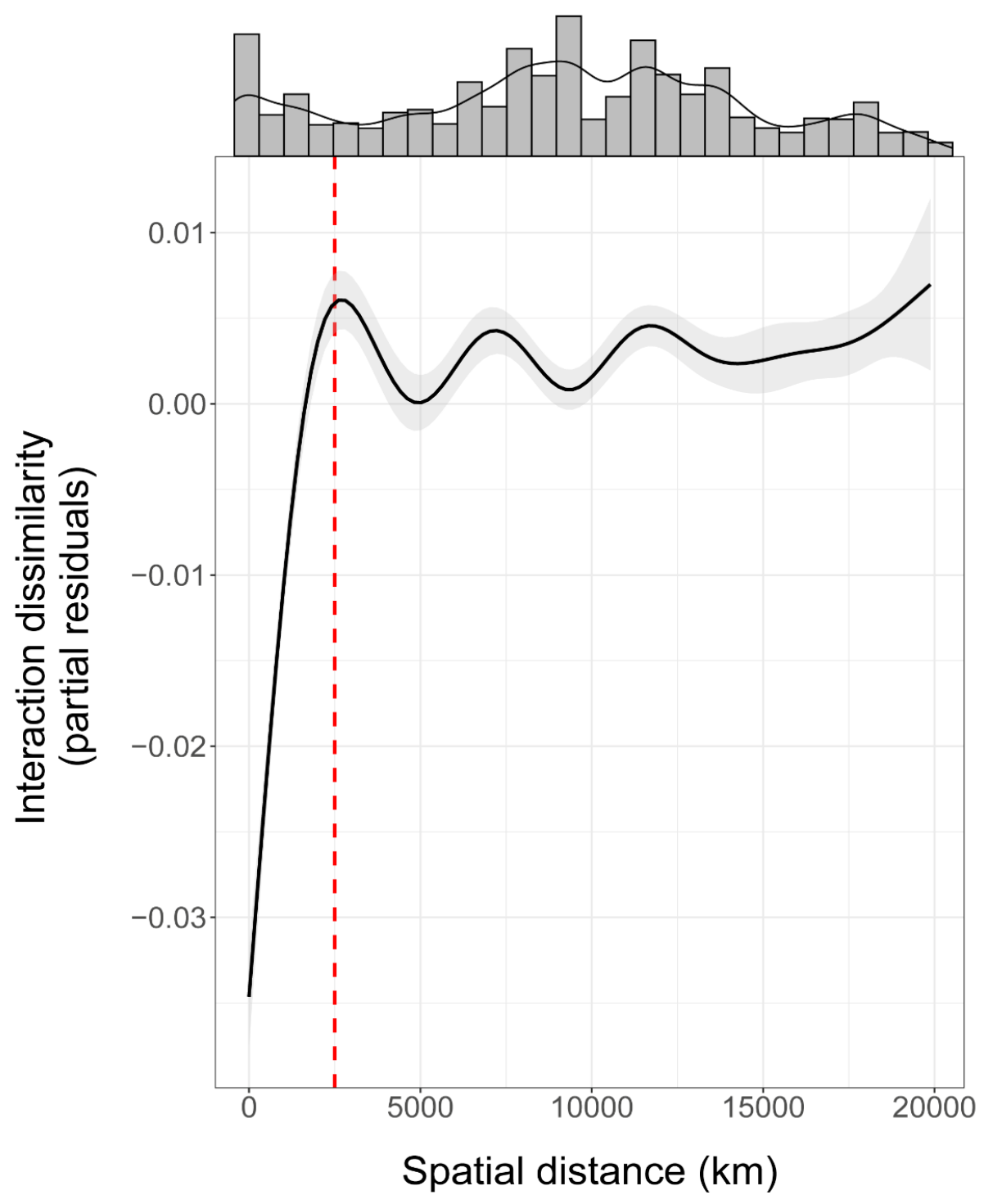

Fig. 5. Partial effects plot of the relationship between spatial distance and interaction

dissimilarity. Here, we show the fit (solid line) of a generalized additive model (GAM) with interaction dissimilarity as response variable and all our predictor variables included. Thus, this plot shows the effect of spatial distance on interaction dissimilarity, while controlling for the effect of the other predictors in the model. The gray area represents the 95\% confidence interval of the fitted GAM. The histogram above the plot shows the distribution of data points across the spatial gradient. Note the sharp increase in interaction dissimilarity until a threshold distance of around 2,500 km (dotted red line), beyond which few networks shared interactions (also see fig. S14). 
Table 1. Multiple drivers of plant-frugivore interaction dissimilarity. Here, we used the binary version of ecoregion and biome distance matrices. $P$ values were calculated using a combination of generalized additive models and multiple regression on distance matrices. EDF represents the effective degrees of freedom for each smooth term in the model. Bold values indicate statistically significant results $(P<0.05) . N$ pairs of networks $=19,110$.

\begin{tabular}{lccc}
\hline Parametric coefficients & Estimate & $\mathbf{t}$ & $\mathbf{p}$ \\
\hline Intercept & 0.997 & 2964.191 & $\mathbf{0 . 0 0 1}$ \\
Ecoregion (same) & -0.070 & -36.401 & $\mathbf{0 . 0 0 1}$ \\
Biome (same) & -0.002 & -3.323 & $\mathbf{0 . 0 4 4}$ \\
\hline Smooth Terms & EDF & $\mathbf{F}$ & $\mathbf{p}$ \\
\hline s (local footprint distance) & 8.534 & 29.988 & $\mathbf{0 . 0 0 1}$ \\
s (spatial distance) & 8.785 & 65.378 & $\mathbf{0 . 0 0 1}$ \\
s (elevational difference) & 6.168 & 47.707 & $\mathbf{0 . 0 0 1}$ \\
s (hours distance) & 1.558 & 5.449 & 0.290 \\
s (months distance) & 5.482 & 6.902 & 0.075 \\
s (years distance) & 7.208 & 11.848 & $\mathbf{0 . 0 1 9}$ \\
s (sampling intensity distance) & 1.018 & 5.182 & 0.259 \\
s (methods distance) & 8.632 & 16.002 & $\mathbf{0 . 0 0 5}$ \\
\hline & & & \\
\hline
\end{tabular}




\section{References and Notes}

1. D. M. Olson, E. Dinerstein, E. D. Wikramanayake, N. D. Burgess, G. V. N. Powell, E. C. Underwood, J. A. D’amico, I. Itoua, H. E. Strand, J. C. Morrison, C. J. Loucks, T. F. Allnutt, T. H. Ricketts, Y. Kura, J. F. Lamoreux, W. W. Wettengel, P. Hedao, K. R. Kassem, Terrestrial ecoregions of the world: a new map of life on Earth. Bioscience 51, 933-938 (2001). doi:10.1641/00063568(2001)051[0933:TEOTWA]2.0.CO;2

2. K. J. Gaston, Global patterns in biodiversity. Nature 405, 220-227 (2000). doi: $10.1038 / 35012228$

3. J. R. Smith, A. D. Letten, P. J. Ke, C. B. Anderson, J. N. Hendershot, M. K. Dhami, G. A. Dlott, T. N. Grainger, M. E. Howard, B. M. L. Morrison, D. Routh, P. A. San Juan, H. A. Mooney, E. A. Mordecai, T. W. Crowther, G. C. Daily, A global test of ecoregions. Nat. Ecol. Evol. 2, 1889-1896 (2018). doi:10.1038/s41559018-0709-X

4. E. Dinerstein, D. Olson, A. Joshi, C. Vynne, N. D. Burgess, E. Wikramanayake, N. Hahn, S. Palminteri, P. Hedao, R. Noss, M. Hansen, H. Locke, E. C. Ellis, B. Jones, C. V. Barber, R. Hayes, C. Kormos, V. Martin, E. Crist, W. Sechrest, L. Price, J. E. M. Baillie, D. Weeden, K. Suckling, C. Davis, N. Sizer, R. Moore, D. Thau, T. Birch, P. Potapov, S. Turubanova, A. Tyukavina, N. De Souza, L.

Pintea, J. C. Brito, O. A. Llewellyn, A. G. Miller, A. Patzelt, S. A. Ghazanfar, J. Timberlake, H. Klöser, Y. Shennan-Farpón, R. Kindt, J. P. B. Lillesø, P. Van Breugel, L. Graudal, M. Voge, K. F. Al-Shammari, M. Saleem, An ecoregionbased approach to protecting half the terrestrial realm. Bioscience 67, 534-545 (2017). doi:10.1093/biosci/bix014 
5. E. Dinerstein, C. Vynne, E. Sala, A. R. Joshi, S. Fernando, T. E. Lovejoy, J.

Mayorga, D. Olson, G. P. Asner, J. E. M. Baillie, N. D. Burgess, K. Burkart, R.

F. Noss, Y. P. Zhang, A. Baccini, T. Birch, N. Hahn, L. N. Joppa, E.

Wikramanayake, A global deal for nature: Guiding principles, milestones, and targets. Sci. Adv. 5, 1-18 (2019). doi:10.1126/sciadv.aaw2869

6. M. Schleuning, J. Fründ, D. García, Predicting ecosystem functions from biodiversity and mutualistic networks: An extension of trait-based concepts to plant-animal interactions. Ecography 38, 380-392 (2015). doi:10.1111/ecog.00983

7. A. Valiente-Banuet, M. A. Aizen, J. M. Alcántara, J. Arroyo, A. Cocucci, M. Galetti, M. B. García, D. García, J. M. Gómez, P. Jordano, R. Medel, L. Navarro, J. R. Obeso, R. Oviedo, N. Ramírez, P. J. Rey, A. Traveset, M. Verdú, R. Zamora, Beyond species loss: the extinction of ecological interactions in a changing world. Funct. Ecol. 29, 299-307 (2015). doi:10.1111/1365-2435.12356

8. M. Schleuning, J. Fründ, O. Schweiger, E. Welk, J. Albrecht, M. Albrecht, M. Beil, G. Benadi, N. Blüthgen, H. Bruelheide, K. Böhning-Gaese, D. M. Dehling, C. F. Dormann, N. Exeler, N. Farwig, A. Harpke, T. Hickler, A. Kratochwil, M. Kuhlmann, I. Kühn, D. Michez, S. Mudri-Stojní, M. Plein, P. Rasmont, A. Schwabe, J. Settele, A. Vujić, C. N. Weiner, M. Wiemers, C. Hof, Ecological networks are more sensitive to plant than to animal extinction under climate change. Nat. Commun. 7, 1-9 (2016). doi:10.1038/ncomms13965

9. C. M. Frost, G. Peralta, T. A. Rand, R. K. Didham, A. Varsani, J. M. Tylianakis, Apparent competition drives community-wide parasitism rates and changes in host abundance across ecosystem boundaries. Nat. Commun. 7, 1-12 (2016). doi:10.1038/ncomms 12644 
10. E. C. Fricke, J. C. Svenning, Accelerating homogenization of the global plantfrugivore meta-network. Nature 585, 74-78 (2020). doi:10.1038/s41586-0202640-y

11. C. Albouy, P. Archambault, W. Appeltans, M. B. Araújo, D. Beauchesne, K. Cazelles, A. R. Cirtwill, M.-J. Fortin, N. Galiana, S. J. Leroux, L. Pellissier, T. Poisot, D. B. Stouffer, S. A. Wood, D. Gravel, The marine fish food web is globally connected. Nat. Ecol. Evol. 3, 1153-1161 (2019). doi:10.1038/s41559019-0950-y

12. D. B. Stouffer, J. Bascompte, Compartmentalization increases food-web persistence. Proc. Natl. Acad. Sci. U.S.A. 108, 3648-3652 (2011). doi:10.1073/pnas.1014353108

13. J. M. Tylianakis, R. J. Morris, Ecological networks across environmental gradients. Annu. Rev. Ecol. Evol. Syst. 48, 25-48 (2017). doi:10.1146/annurev-ecolsys$110316-022821$

14. J. M. Tylianakis, T. Tscharntke, O. T. Lewis, Habitat modification alters the structure of tropical host-parasitoid food webs. Nature 445, 202-205 (2007). doi:10.1038/nature05429

15. C. Capinha, F. Essl, H. Seebens, D. Moser, H. M. Pereira, The dispersal of alien species redefines biogeography in the Anthropocene. Science 348, 1248-1251 (2015). doi:10.1126/science.aaa8913

16. H. Qian, R. E. Ricklefs, Disentangling the effects of geographic distance and environmental dissimilarity on global patterns of species turnover. Glob. Ecol. Biogeogr. 21, 341-351 (2012). doi:10.1111/j.1466-8238.2011.00672.x 
17. C. Emer, M. Galetti, M. A. Pizo, P. R. Guimarães, S. Moraes, A. Piratelli, P. Jordano, Seed-dispersal interactions in fragmented landscapes - a metanetwork approach. Ecol. Lett. 21, 484-493 (2018). doi:10.1111/ele.12909

18. D. M. Dehling, G. Peralta, I. M. A. Bender, P. G. Blendinger, K. Böhning-Gaese, M. C. Muñoz, E. L. Neuschulz, M. Quitián, F. Saavedra, V. Santillán, M. Schleuning, D. B. Stouffer, Similar composition of functional roles in Andean seed-dispersal networks, despite high species and interaction turnover. Ecology 101, 1-11 (2020). doi:10.1002/ecy.3028

19. M. Quitián, V. Santillán, C. I. Espinosa, J. Homeier, K. Böhning-Gaese, M.

Schleuning, E. L. Neuschulz, Elevation-dependent effects of forest fragmentation on plant-bird interaction networks in the tropical Andes. Ecography 41, 14971506 (2018). doi:10.1111/ecog.03247

20. P. Jordano. "Fruits and frugivory" in Seeds: The Ecology of regeneration in plant communities, R.S. Gallagher, Ed. (CABI, Wallingford, UK, ed. 3, 2014), pp. 1861.

21. R. E. Onstein, W. J. Baker, T. L. P. Couvreur, S. Faurby, J. C. Svenning, W. D. Kissling, Frugivory-related traits promote speciation of tropical palms. Nat. Ecol. Evol. 1, 1903-1911 (2017). doi:10.1038/s41559-017-0348-7

22. J. M. Wunderle, The role of animal seed dispersal in accelerating native forest regeneration on degraded tropical lands. For. Ecol. Manage. 99, 223-235 (1997). doi:10.1016/S0378-1127(97)00208-9

23. Materials and methods are available as supplementary materials at the Science website. 
24. O. Venter, E. W. Sanderson, A. Magrach, J. R. Allan, J. Beher, K. R. Jones, H. P. Possingham, W. F. Laurance, P. Wood, B. M. Fekete, M. A. Levy, J. E. M. Watson, Global terrestrial human footprint maps for 1993 and 2009. Sci. Data. 3, 1-10 (2016). doi:10.1038/sdata.2016.67

25. T. Poisot, E. Canard, D. Mouillot, N. Mouquet, D. Gravel, The dissimilarity of species interaction networks. Ecol. Lett. 15, 1353-1361 (2012). doi:10.1111/ele.12002

26. J. W. Lichstein, Multiple regression on distance matrices: a multivariate spatial analysis tool. Plant Ecol. 188, 117-131 (2007). doi:10.1007/s11258-006-9126-3

27. K. R. McConkey, S. Prasad, R. T. Corlett, A. Campos-Arceiz, J. F. Brodie, H. Rogers, L. Santamaria, Seed dispersal in changing landscapes. Biol. Conserv. 146, 1-13 (2012). doi:10.1016/j.biocon.2011.09.018

28. J. Vizentin-Bugoni, C. E. Tarwater, J. T. Foster, D. R. Drake, J. M. Gleditsch, A. M. Hruska, J. Patrick Kelley, J. H. Sperry, Structure, spatial dynamics, and stability of novel seed dispersal mutualistic networks in Hawai'i. Science 364, 78-82 (2019). doi:10.1126/science.aau8751

29. J. Bascompte, P. Jordano, C. J. Melian, J. M. Olesen, The nested assembly of plantanimal mutualistic networks. Proc. Natl. Acad. Sci. U.S.A. 100, 9383-9387 (2003). doi:10.1073/pnas.1633576100

30. D. García, D. Martínez, D. B. Stouffer, J. M. Tylianakis, Exotic birds increase generalization and compensate for native bird decline in plant-frugivore assemblages. J. Anim. Ecol. 83, 1441-1450 (2014). doi:10.1111/13652656.12237 
31. T. Poisot, G. Bergeron, K. Cazelles, T. Dallas, D. Gravel, A. MacDonald, B. Mercier, C. Violet, S. Vissault, Global knowledge gaps in species interaction networks data. J. Biogeogr. 48,1552-1563 (2021). doi:10.1111/jbi.14127

32. J. R. Smith, J. N. Hendershot, N. Nova, G. C. Daily, The biogeography of ecoregions: descriptive power across regions and taxa. J. Biogeogr. 47, 14131426 (2020). doi:10.1111/jbi.13871

33. W. D. Kissling, K. Böhning-Gaese, W. Jetz, The global distribution of frugivory in birds. Glob. Ecol. Biogeogr. 18, 150-162 (2009). doi:10.1111/j.14668238.2008.00431.x

34. L. P. Martins et al., Data and Code for 'Global and regional ecological boundaries drive abrupt changes in avian frugivory interactions.'

35. M. A. Fortuna et al., https://arxiv.org/abs/1403.2575 (2014).

36. Global Names Resolver: Global Names resolution tools and services (2020); https://resolver.globalnames.org.

37. S. A. Chamberlain, E. Szöcs, taxize: Taxonomic search and retrieval in R. F1000Research 2, 191 (2013). doi:10.12688/f1000research.2-191.v2

38. T. Rees, Taxamatch, an algorithm for near ('fuzzy') matching of scientific names in taxonomic databases. PLoS One 9, e107510 (2014). doi:10.1371/journal.pone.0107510

39. National Center for Biotechnology Information (2020); https://www.ncbi.nlm.nih.gov

40. BirdLife International (2020); https://www.birdlife.org/ 
41. Integrated Taxonomic Information System (2020); https://itis.gov/

42. Handbook of the birds of the world and BirdLife International digital checklist of the birds of the world. Version 4.0 (2019); http://datazone.birdlife.org/species/taxonomy

43. Avibase, The world bird database (2020); https://avibase.bsc-eoc.org

44. R Core Team, R: A Language and Environment for Statistical Computing (R Foundation for Statistical Computing, 2020); www.r-project.org/

45. International Plant Name Index (2020); https://www.ipni.org/

46. Tropicos: connecting the world to botanical data since 1982 (2020);

\section{http://www.tropicos.org}

47. IPlant collaborative (2020); http://tnrs.iplantcollaborative.org/

48. GBIF: The Global Biodiversity Information Facility. What is GBIF? (2020); https://www.gbif.org/what-is-gbif

49. S. Chamberlain, V. Barve, D. Mcglinn, D. Oldoni, P. Desmet, L. Geffert, K. Ram, rgbif: Interface to the Global Biodiversity Information Facility API. R package version 1.4.0 (2021); https://CRAN.R-project.org/package=rgbif

50. E. F. Cagua et al., https://www.biorxiv.org/content/10.1101/866772v1 (2019).

51. S. Gaiji, V. Chavan, A. H. Ariño, J. Otegui, D. Hobern, R. Sood, E. Robles, Content assessment of the primary biodiversity data published through GBIF network: Status, challenges and potentials. Biodivers. Informatics 8, 94-172 (2013). doi:10.17161/bi.v8i2.4124

52. A. Zizka, D. Silvestro, T. Andermann, J. Azevedo, C. Duarte Ritter, D. Edler, H. 
Farooq, A. Herdean, M. Ariza, R. Scharn, S. Svantesson, N. Wengström, V.

Zizka, A. Antonelli, CoordinateCleaner: standardized cleaning of occurrence records from biological collection databases. Methods Ecol. Evol. 10, 744-751

(2019). doi:10.1111/2041-210X.13152

53. Natural Earth (2020); http://www.naturalearthdata.com/

54. R. J. Hijmans, S. E. Cameron, J. L. Parra, P. G. Jones, A. Jarvis, Very high resolution interpolated climate surfaces for global land areas. Int. J. Climatol. 25, 1965-1978 (2005). doi:10.1002/joc.1276

55. R. J. Hijmans, raster: Geographic Data Analysis and Modeling. R package version 3.0-2 (2019); https://cran.r-project.org/package=raster

56. J. Oksanen, F. G. Blanchet, M. Friendly, R. Kindt, P. Legendre, D. McGlinn, P. R. Minchin, R. B. O’ Hara, G. L. Simpson, P. Solymos, M. H. H. Stevens, E. Szoecs, H. Wagner, Vegan: community ecology package. R package version 2.53 (2019); http://CRAN.R-project.org/package=vegan.

57. Google Earth (2020); https://www.google.com/earth/

58. G. Peralta, G. L. W. Perry, D. P. Vázquez, D. M. Dehling, J. M. Tylianakis, Strength of niche processes for species interactions is lower for generalists and exotic species. J. Anim. Ecol. 89, 2145-2155 (2020). doi:10.1111/13652656.13274

59. P. Jordano, Sampling networks of ecological interactions. Funct. Ecol. 30, 1883 1893 (2016). doi:10.1111/1365-2435.12763

60. S. Pavoine, J. Vallet, A.B. Dufour, S. Gachet, H. Daniel, On the challenge of treating various types of variables: application for improving the measurement of 
functional diversity. Oikos 118, 391-402 (2009). doi:10.1111/j.1600-

0706.2008.16668.x

61. S. Dray, A. B. Dufour, The ade4 package: implementing the duality diagram for ecologists. J. Stat. Softw. 22, 1-20 (2007). doi:10.18637/jss.v022.i04

62. T. Poisot, betalink: Beta-diversity of species interactions. R package version 2.2.1. (2016); https://CRAN.R-project.org/package=betalink.

63. C. Banašek-Richter, L. F. Bersier, M. F. Cattin, R. Baltensperger, J. P. Gabriel, Y. Merz, R. E. Ulanowicz, A. F. Tavares, D. D. Williams, P. C. De Ruiter, K. O. Winemiller, R. E. Naisbit, Complexity in quantitative food webs. Ecology 90, 1470-1477 (2009). doi:10.1890/08-2207.1

64. E. Thébault, C. Fontaine, Stability of ecological communities and the architecture of mutualistic and trophic networks. Science 329, 853-856 (2010). doi:10.1126/science. 1188321

65. M. A. Fortuna, D. B. Stouffer, J. M. Olesen, P. Jordano, D. Mouillot, B. R. Krasnov, R. Poulin, J. Bascompte, Nestedness versus modularity in ecological networks: two sides of the same coin? J. Anim. Ecol. 79, 811-817 (2010). doi:10.1111/j.1365-2656.2010.01688.x

66. L. F. Bersier, C. Banašek-Ricther, M. F. Cattin, Quantitative descriptors of foodweb matrices. Ecology 83, 2934-2407 (2002). doi:10.1890/00129658(2002)083[2394:QDOFWM]2.0.CO;2

67. M. Almeida-Neto, W. Ulrich, A straightforward computational approach for measuring nestedness using quantitative matrices. Environ. Model. Softw. 26, 173-178 (2011). doi:10.1016/j.envsoft.2010.08.003 
68. U. Bastolla, M. A. Fortuna, A. Pascual-García, A. Ferrera, B. Luque, J. Bascompte, The architecture of mutualistic networks minimizes competition and increases biodiversity. Nature 458, 1018-1020 (2009). doi:10.1038/nature07950

69. N. Blüthgen, J. Fründ, D. P. Vazquez, F. Menzel, What do interaction network metrics tell us about specialization and biological traits? Ecology 89, 3387-3399 (2008). doi:10.1890/07-2121.1

70. T. Poisot, E. Canard, N. Mouquet, M. E. Hochberg, A comparative study of ecological specialization estimators. Methods Ecol. Evol. 3, 537-544 (2012). doi:10.1111/j.2041-210X.2011.00174.X

71. S. J. Beckett, Improved community detection in weighted bipartite networks. R. Soc. Open Sci. 3, 140536 (2016). doi:10.1098/rsos.140536

72. J. M. Olesen, J. Bascompte, Y. L. Dupont, P. Jordano, The modularity of pollination networks. Proc. Natl. Acad. Sci. U.S.A. 104, 19891-19896 (2007). doi:10.1073/pnas.0706375104

73. J. Vizentin-Bugoni, P. K. Maruyama, V. J. Debastiani, L. S. Duarte, B. Dalsgaard, M. Sazima, Influences of sampling effort on detected patterns and structuring processes of a Neotropical plant-hummingbird network. J. Anim. Ecol. 85, 262272 (2016). doi:10.1111/1365-2656.12459

74. C. F. Dormann, J. Frund, N. Bluthgen, B. Gruber, Indices, graphs and null models: analyzing bipartite ecological networks. Open Ecol. J. 2, 7-24 (2009). doi:10.2174/1874213000902010007

75. S. N. Wood, Thin plate regression splines. J. R. Stat. Soc. Ser. B Stat. Methodol. 65, 95-114 (2003). doi:10.1111/1467-9868.00374 
76. S. N. Wood, Fast stable restricted maximum likelihood and marginal likelihood estimation of semiparametric generalized linear models. J. R. Stat. Soc. Ser. B Stat. Methodol. 73, 3-36 (2011). doi:10.1111/j.1467-9868.2010.00749.x

77. S. C. Goslee, D. L. Urban, The ecodist package for dissimilarity-based analysis of ecological data. J. Stat. Softw. 22, 1-19 (2007). doi:10.18637/jss.v022.i07

78. A. R. Cirtwill, D. B. Stouffer, T. N. Romanuk, Latitudinal gradients in biotic niche breadth vary across ecosystem types. Proc. R. Soc. B Biol. Sci. 282, 20151589 (2015). doi:10.1098/rspb.2015.1589

79. M. G. R. Vollstädt, S. W. Ferger, A. Hemp, K. M. Howell, K. Böhning-Gaese, M. Schleuning, Seed-dispersal networks respond differently to resource effects in open and forest habitats. Oikos 127, 847-854 (2018). doi:10.1111/oik.04703

80. J. Fründ, Dissimilarity of species interaction networks: how to partition rewiring and species turnover components. Ecosphere 12, e03653 (2021). doi:10.1002/ecs2.3653.

81. S. N. Wood, F. Scheipl, gamm4: Generalized Additive Mixed Models using 'mgcv' and 'lme4'. R package version 0.2-6 (2020); https://cran.rproject.org/package $=$ gamm 4

82. J. W. Baird, The selection and use of fruit by birds in an eastern forest. Wilson Bull. 92, 63-73 (1980).

83. T. A. Carlo, J. A. Collazo, M. J. Groom, Avian fruit preferences across a Puerto Rican forested landscape: pattern consistency and implications for seed removal. Oecologia 134, 119-131 (2003). doi:10.1007/s00442-002-1087-1

84. P. G. H. Frost, Fruit-frugivore interactions in a South African coastal dune forest. 
Acta XVII Congressus Internationalis Ornithologici 2, 1179-1184 (1980).

85. M. Galetti, M. A. Pizo, Fruit eating by birds in a forest fragment in southeastern Brazil. Ararajuba 4, 71-79 (1996).

86. G. E. Kantak, Observations on some fruit-eating birds in Mexico. Auk 96, 183-186 (1979). doi:10.1093/auk/96.1.183

87. A. E. Sorensen, Interactions between birds and fruit in a temperate woodland. Oecologia 50, 242-249 (1981). doi:10.1007/BF00348046

88. W. R. Silva, "Patterns of fruit-frugivores interactions in two Atlantic Forest bird communities of South-eastern Brazil: Implications for conservation," in Seed Dispersal and Frugivory: Ecology, Evolution, and Conservation, D. J. Levey, W. R. Silva, M. Galetti, Eds. (CAB International, 2002), pp. 423-435.

89. S. L. M. Rodrigues, "Rede de Interações entre aves frugívoras e plantas em uma área de Mata Atlântica no Sudeste do Brasil”, thesis, Universidade Federal de São Carlos, Sorocaba, SP (2015).

90. E. R. Castro, "Fenologia reprodutiva do palmito Euterpe edulis (Arecaceae) e sua influência na abundância de aves frugívoras na floresta Atlântica”, thesis, UNESP, Rio Claro, SP (2007).

91. J. M. S. Correia, "Utilização de espécies frutíferas da Mata Atlântica na alimentação da avifauna da Reserva Biológica de Poços das Antas”, thesis, UNDB, Brasília, DF (1997).

92. K. J. F. Alves, “Composição da avifauna e frugivoria por aves em um mosaico sucessional na Mata Atlântica”, thesis, UNESP, Rio Claro, SP (2008).

93. R. F. Fadini, P. de Marco Jr, Interações entre aves frugívoras e plantas em um 
fragmento de mata atlântica de Minas Gerais. Ararajuba 12, 97-103 (2004).

94. A. Kindel, "Interações entre plantas ornitocóricas e aves frugívoras na Estação Ecológica de Aracuri, Muitos Capões, RS”, thesis, UFRGS, Porto Alegre, RS (1996).

95. M. A. Pizo, Frugivory and habitat use by fruit-eating birds in a fragmented landscape of southeast Brazil. Ornitol. Neotrop. 15, 117-126 (2004).

96. S. Athiê, “Composição da avifauna e frugivoria por aves em um mosaico de vegetação secundária em Rio Claro, região centro-leste do estado de São Paulo”, thesis, UFSCAR, São Carlos, SP (2009).

97. F. R. Silva, D. Montoya, R. Furtado, J. Memmott, M. A. Pizo, R. R. Rodrigues, The restoration of tropical seed dispersal networks. Restor. Ecol. 23, 852-860 (2015). doi:10.1111/rec.12244

98. E. Hasui, “O papel das aves frugívoras na dispersão de sementes em um fragmento de floresta semidecídua secundária em São Paulo”, thesis, USP, São Paulo, SP (1994).

99. V. Robinson, "Índice de importância de diferentes espécies de plantas na atração de aves para uma área reflorestada em Piracicaba”, thesis, UNESP, Rio Claro, SP (2015).

100. R. F. M. Silva, "Interações entre plantas e aves frugívoras no campus da Universidade Federal do Rio de Janeiro", thesis, UFRJ, Rio de Janeiro, RJ (2011).

101. R. H. Heleno, J. A. Ramos, J. Memmott, Integration of exotic seeds into an Azorean seed dispersal network. Biol. Invasions 15, 1143-1154 (2013). 
doi:10.1007/s10530-012-0357-z

102. M. Schleuning, N. Blüthgen, M. Flörchinger, J. Braun, H. M. Schaefer, K.

Böhning-Gaese, Specialization and interaction strength in a tropical plant frugivore network differ among forest strata. Ecology 92, 26-36 (2011). doi:10.1890/09-1842.1

103. I. Schneiberg, D. Boscolo, M. Devoto, V. Marcilio-Silva, C. A. Dalmaso, J. W. Ribeiro, M. C. Ribeiro, A. C. Guaraldo, B. B. Niebuhr, I. G. Varassin, Urbanization homogenizes the interactions of plant-frugivore bird networks. Urban Ecosyst. 23, 457-470 (2020). doi:10.1007/s11252-020-00927-1

104. T. Machado-de-Souza, R. P. Campos, M. Devoto, I. G. Varassin, Local drivers of the structure of a tropical bird-seed dispersal network. Oecologia 189, 421-433 (2019). doi:10.1007/s00442-018-4322-0

105. A. González-Castro, A. Traveset, M. Nogales, Seed dispersal interactions in the Mediterranean Region: contrasting patterns between islands and mainland. $J$. Biogeogr. 39, 1938-1947 (2012). doi:10.1111/j.1365-2699.2012.02693.x

106. T. C. Faustino, C. G. Machado, Frugivoria por aves em uma área de campo rupestre na Chapada Diamantina, BA. Rev. Bras. Ornitol. 14, 137-143 (2006).

107. P. Jordano, El ciclo anual de los paseriformes frugívoros en el matorral mediterráneo del sur de España: importancia de su invernada y variaciones interanuales. Ardeola 32, 69-94 (1985).

108. F. Saavedra, I. Hensen, S. G. Beck, K. Böhning-Gaese, D. Lippok, T. Töpfer, M. Schleuning, Functional importance of avian seed dispersers changes in response to human-induced forest edges in tropical seed-dispersal networks. Oecologia 
176, 837-848 (2014). doi:10.1007/s00442-014-3056-x

109. N. Noma, T. Yumoto, Fruiting phenology of animal-dispersed plants in response to winter migration of frugivores in a warm temperate forest on Yakushima Island, Japan. Ecol. Res. 12, 119-129 (1997). doi:10.1007/BF02523777

110. G. B. M. da Silva, F. Pedroni, Frugivoria por aves em área de cerrado no município de Uberlândia, Minas Gerais. Rev. Árvore 38, 433-442 (2014). doi:10.1590/S0100-67622014000300005

111. D. C. Acosta-Rojas, M. V. Jiménez-Franco, V. M. Zapata-Pérez, P. De La Rúa, V. Martínez-López, An integrative approach to discern the seed dispersal role of frugivorous guilds in a Mediterranean semiarid priority habitat. PeerJ 2019, 1-22 (2019). doi:10.7717/peerj.7609

112. R. Naniwadekar, S. Chaplod, A. Datta, A. Rathore, H. Sridhar, Large frugivores matter: insights from network and seed dispersal effectiveness approaches. $J$. Anim. Ecol. 88, 1250-1262 (2019). doi:10.1111/1365-2656.13005

113. S. Montoya-Arango, J. F. Acevedo-Quintero, J. L. Parra, Abundance and size of birds determine the position of the species in plant-frugivore interaction networks in fragmented forests. Community Ecol. 20, 75-82 (2019). doi:10.1556/168.2019.20.1.8

114. D. García, I. Donoso, J. Rodríguez-Pérez, Frugivore biodiversity and complementarity in interaction networks enhance landscape-scale seed dispersal function. Funct. Ecol. 32, 2742-2752 (2018). doi:10.1111/1365-2435.13213

115. G. Casas, V. A. G. Bastazini, V. J. Debastiani, V. D. Pillar, Assessing sampling sufficiency of network metrics using bootstrap. Ecol. Complex. 36, 268-275 
(2018). doi:10.1016/j.ecocom.2018.09.005

116. E. C. Fricke, J. J. Tewksbury, H. S. Rogers, Defaunation leads to interaction deficits, not interaction compensation, in an island seed dispersal network. Glob. Chang. Biol. 24, e190-e200 (2018). doi:10.1111/gcb.13832

117. B. Rumeu, M. Devoto, A. Traveset, J. M. Olesen, P. Vargas, M. Nogales, R. Heleno, Predicting the consequences of disperser extinction: richness matters the most when abundance is low. Funct. Ecol. 31, 1910-1920 (2017). doi:10.1111/1365-2435.12897

118. N. Farwig, D. G. Schabo, J. Albrecht, Trait-associated loss of frugivores in fragmented forest does not affect seed removal rates. J. Ecol. 105, 20-28 (2017). doi:10.1111/1365-2745.12669

119. D. L. Gorchov, F. Cornejo, C. F. Ascorra, M. Jaramillo, Dietary overlap between frugivorous birds and bats in the Peruvian Amazon. Oikos 74, 235-250 (1995). doi: $10.2307 / 3545653$

120. T. A. Carlo, J. M. Morales, Generalist birds promote tropical forest regeneration and increase plant diversity via rare-biased seed dispersal. Ecology 97, 18191831 (2016). doi:10.1890/15-2147.1

121. M. Ramos-Robles, E. Andresen, C. Díaz-Castelazo, Temporal changes in the structure of a plant-frugivore network are influenced by bird migration and fruit availability. PeerJ 2016, 1-21 (2016). doi:10.7717/peerj.2048

122. R. Sarmento, C. P. Alves-Costa, A. Ayub, M. A. R. Mello, Partitioning of seed dispersal services between birds and bats in a fragment of the Brazilian Atlantic Forest. Zoologia 31, 245-255 (2014). doi:10.1590/S1984-46702014000300006 
123. J. C. Cruz, J. A. Ramos, L. P. da Silva, P. Q. Tenreiro, R. H. Heleno, Seed dispersal networks in an urban novel ecosystem. Eur. J. For. Res. 132, 887-897 (2013). doi:10.1007/s10342-013-0722-1

124. K. C. Burns, What causes size coupling in fruit-frugivore interaction webs? Ecology 94, 295-300 (2013). doi:10.1890/12-1161.1

125. P. C. Andrade, J. V. L. Mota, A. A. F. de Carvalho, Interações mutualísticas entre aves frugívoras e plantas em um fragmento urbano de Mata Atlântica, Salvador, BA. Rev. Bras. Ornitol. 19, 63-73 (2011).

126. N. Velho, J. Ratnam, U. Srinivasan, M. Sankaran, Shifts in community structure of tropical trees and avian frugivores in forests recovering from past logging. Biol. Conserv. 153, 32-40 (2012). doi:10.1016/j.biocon.2012.04.028

127. C. F. O’Donnell, P. J. Dilks, Foods and foraging of forest birds in temperate rainforest, South Westland, New Zealand. N. Z. J. Ecol. 18, 87-107 (1994).

128. J. M. Costa, L. P. da Silva, J. A. Ramos, R. H. Heleno, Sampling completeness in seed dispersal networks: when enough is enough. Basic Appl. Ecol. 17, 155-164 (2016). doi:10.1016/j.baae.2015.09.008

129. S. Timóteo, M. Correia, S. Rodríguez-Echeverría, H. Freitas, R. Heleno, Multilayer networks reveal the spatial structure of seed-dispersal interactions across the Great Rift landscapes. Nat. Commun. 9, 140 (2018). doi:10.1038/s41467-017-02658-y

130. J. P. David, B. S. Murugan, R. Manakadan, Frugivory by birds and mammals in Sriharikota Island, southern India. J. Bombay Nat. Hist. Soc. 108, 24-40 (2011). 
Lunardi, Fruiting phenology and consumption of zoochoric fruits by wild vertebrates in a seasonally dry tropical forest in the Brazilian Caatinga. Acta Oecologica 105, 103553 (2020). doi:10.1016/j.actao.2020.103553

132. T. K. Pratt, E. W. Stiles, The influence of fruit size and structure on composition of frugivore assemblages in New Guinea. Biotropica 17, 314-321 (1985). doi:10.2307/2388594

133. E. D. Brown, M. J. G. Hopkins, Tests of disperser specificity between frugivorous birds and rainforest fruits in New Guinea. Еmu 102, 137-146 (2002). doi:10.1071/MU00082

134. G. Kopij, Winter diet of frugivorous birds in the suburbs of Bloemfontein, South Africa. African J. Wildl. Res. 30, 163-165 (2000).

135. M. C. Stanley, A. Lill, Avian fruit consumption and seed dispersal in a temperate Australian woodland. Austral Ecol. 27, 137-148 (2002). doi:10.1046/j.14429993.2002.01166.x

136. K. French, Evidence for frugivory by birds in montane and lowland forests in south-east Australia. Emu 90, 185-189 (1990). doi:10.1071/MU9900185

137. P. A. Williams, B. J. Karl, Fleshy fruits of indigenous and adventive plants in the diet of birds in forest remnants, Nelson, New Zealand. N. Z. J. Ecol. 20, 127-145 (1996).

138. V. S. M. Gomes, "Variação espacial e dieta de aves terrestres na restinga de Jurubatiba, RJ", thesis, UFRJ, Rio de Janeiro, RJ (2006).

139. J. C. Motta Jr., “A exploração de frutos como alimento por aves de mata ciliar numa região do Distrito Federal”, thesis, UNESP, Rio Claro, SP (1991). 
140. M. M. Argel-de-Oliveira, "Frugivoria por aves em um fragmento de floresta de restinga no estado do Espírito Santo, Brasil”, thesis, UNICAMP, Campinas, SP (1999).

141. K. G. Ikuta, F. C. Martins, Interação entre aves frugívoras e plantas no Parque Estadual da Cantareira, estado de São Paulo. Atualidades Ornitológicas 172, 3336 (2013).

142. C. I. Donatti, P. R. Guimarães, M. Galetti, M. A. Pizo, F. M. D. Marquitti, R. Dirzo, Analysis of a hyper-diverse seed dispersal network: modularity and underlying mechanisms. Ecol. Lett. 14, 773-781 (2011). doi:10.1111/j.14610248.2011.01639.x

143. M. J. C. Gondim, “A exploração de frutos por aves frugívoras em uma área de Cerradão no Estado de São Paulo”, thesis, UNESP, Rio Claro, SP (2002).

144. R. A. Ruggera, P. G. Blendinger, M. D. Gomez, C. Marshak, Linking structure and functionality in mutualistic networks: do core frugivores disperse more seeds than peripheral species? Oikos 125, 541-555 (2016). doi:10.1111/oik.02204

145. P. G. Blendinger, J. Jiménez, L. Macchi, E. Martín, M. S. Sánchez, M. M. Ayup, Scale-dependent spatial match between fruits and fruit-eating birds in Andean mountain forests. Biotropica 47, 702-711 (2015). doi:10.1111/btp.12247

146. P. G. Blendinger, R. A. Ruggera, M. G. Núñez Montellano, L. Macchi, P. V. Zelaya, M. E. Álvarez, E. Martín, O. O. Acosta, R. Sánchez, J. Haedo, Finetuning the fruit-tracking hypothesis: spatiotemporal links between fruit availability and fruit consumption by birds in Andean mountain forests. J. Anim. Ecol. 81, 1298-1310 (2012). doi:10.1111/j.1365-2656.2012.02011.x 
147. Í. Menezes Pinto, C. Emer, E. Cazetta, J. C. Morante-Filho, Deforestation simplifies understory bird seed-dispersal networks in human-modified landscapes. Front. Ecol. Evol. 9, 1-12 (2021). doi:10.3389/fevo.2021.640210

148. W. A. Boyle, C. J. Conway, J. L. Bronstein, Why do some, but not all, tropical birds migrate? A comparative study of diet breadth and fruit preference. Evol. Ecol. 25, 219-236 (2011). doi:10.1007/s10682-010-9403-4

149. F. H. J. Crome, Foraging ecology of an assemblage of birds in lowland rainforest in northern Queensland. Aust. J. Ecol. 3, 195-212 (1978). doi:10.1111/j.14429993.1978.tb01170.x

150. A. Gopal, D. Mudappa, T. R. S. Raman, R. Naniwadekar, Forest cover and fruit crop size differentially influence frugivory of select rainforest tree species in Western Ghats, India. Biotropica 52, 871-883 (2020). doi:10.1111/btp.12810

151. H. Li, L. Tang, C. Jia, M. Holyoak, J. Fründ, X. Huang, Z. Xiao, The functional roles of species in metacommunities, as revealed by metanetwork analyses of bird-plant frugivory networks. Ecol. Lett. 23, 1252-1262 (2020). doi:10.1111/ele.13529

152. C. M. Herrera, A study of avian frugivores, bird-dispersed plants, and their interaction in Mediterranean scrublands. Ecol. Monogr. 54, 1-23 (1984). doi: $10.2307 / 1942454$

153. M. Plein, L. Längsfeld, E. L. Neuschulz, C. Schultheiß, L. Ingmann, T. Töpfer, K. Böhning-Gaese, M. Schleuning, Constant properties of plant-frugivore networks despite fluctuations in fruit and bird communities in space and time. Ecology $\mathbf{9 4}$, 1296-1306 (2013). doi:10.1890/12-1213.1 
154. H. Stiebel, "Frugivorie bei mitteleuropäischen Vögeln”, thesis, Universität Oldenburg (2003).

155. M. C. Muñoz, H. M. Schaefer, K. Böhning-Gaese, M. Schleuning, Importance of animal and plant traits for fruit removal and seedling recruitment in a tropical forest. Oikos 126, 823-832 (2017). doi:10.1111/oik.03547

156. D. M. Dehling, T. Töpfer, H. M. Schaefer, P. Jordano, K. Böhning-Gaese, M. Schleuning, Functional relationships beyond species richness patterns: trait matching in plant-bird mutualisms across scales. Glob. Ecol. Biogeogr. 23, 10851093 (2014). doi:10.1111/geb.12193

157. G. Buitrón-Jurado, “Diversidad de aves frugívoras y árboles, redes de interacción e identificación de árboles magnetos en dos bosques nublados de Venezuela con distintas condiciones de fragmentación”, thesis, Instituto Venezolano de Investigaciones Científicas, Miranda, Venezuela (2012).

158. P. Balasubramanian, Interactions between fruit-eating birds and bird-dispersed plants in the tropical dry evergreen forest of Point Calimere, South India. $J$. Bombay Nat. Hist. Soc. 93, 428-441 (1996).

159. C. G. Chimera, D. R. Drake, Patterns of seed dispersal and dispersal failure in a hawaiian dry forest having only introduced birds. Biotropica 42, 493-502 (2010). doi:10.1111/j.1744-7429.2009.00610.x

160. M. Githiru, L. Lens, L. A. Bennur, C. P. K. O. Ogol, Effects of site and fruit size on the composition of avian frugivore assemblages in a fragmented Afrotropical forest. Oikos 96, 320-330 (2002). doi:10.1034/j.1600-0706.2002.960214.x

161. P. K. Malmborg, M. F. Willson, Foraging ecology of avian frugivores and some 
consequences for seed dispersal in an Illinois woodlot. Condor 90, 173-186 (1988). doi:10.2307/1368446

162. E. N. Spotswood, J. Y. Meyer, J. W. Bartolome, An invasive tree alters the structure of seed dispersal networks between birds and plants in French Polynesia. J. Biogeogr. 39, 2007-2020 (2012). doi:10.1111/j.13652699.2012.02688.x

163. J. D. Wolfe, M. D. Johnson, C. J. Ralph, Do birds select habitat or food resources? Nearctic-neotropic migrants in northeastern Costa Rica. PLoS One 9, e86221 (2014). doi:10.1371/journal.pone.0086221

164. C. C. Chen, L. S. Chou, The diet of forest birds at Fushan Experimental Forest. Taiwan J. For. Sci. 14, 275-287 (1999).

165. M. Kamruzzaman, G. S. M. Asmat, Seasonal variations of fruit preference among frugivorous birds in Chittagong, Bangladesh. Bangladesh J. Zool. 36, 187-206 (2008).

166. J. M. Palmeirim, D. L. Gorchov, S. Stoleson, Trophic structure of a neotropical frugivore community: is there competition between birds and bats? Oecologia 79, 403-411 (1989). doi:10.1007/BF00384321

167. J. G. Blake, B. A. Loiselle, Fruits in the diets of neotropical migrant birds in Costa Rica. Biotropica 24, 200-210 (1992). doi:10.2307/2388674

168. A. Traveset, Resultats preliminars sobre el consum de fruits per ocells a l'illa de Cabrera (Illes Balears). Anu. Ornitològic les Balear 7, 3-9 (1992).

169. M. Schleuning, J. Fründ, A. M. Klein, S. Abrahamczyk, R. Alarcón, M. Albrecht, G. K. S. Andersson, S. Bazarian, K. Böhning-Gaese, R. Bommarco, B. 
Dalsgaard, D. M. Dehling, A. Gotlieb, M. Hagen, T. Hickler, A. Holzschuh, C.

N. Kaiser-Bunbury, H. Kreft, R. J. Morris, B. Sandel, W. J. Sutherland, J. C.

Svenning, T. Tscharntke, S. Watts, C. N. Weiner, M. Werner, N. M. Williams, C.

Winqvist, C. F. Dormann, N. Blüthgen, Specialization of mutualistic interaction networks decreases toward tropical latitudes. Curr. Biol. 22, 1925-1931 (2012). doi:10.1016/j.cub.2012.08.015

170. B. Dalsgaard, M. Schleuning, P. K. Maruyama, D. M. Dehling, J. Sonne, J. Vizentin-Bugoni, T. B. Zanata, J. Fjeldså, K. Böhning-Gaese, C. Rahbek, Opposed latitudinal patterns of network-derived and dietary specialization in avian plant-frugivore interaction systems. Ecography 40, 1395-1401 (2017). doi:10.1111/ecog.02604

171. A. Chao, R. K. Colwell, C. Lin, N. J. Gotelli, Sufficient sampling for asymptotic minimum species richness estimators. Ecology 90, 1125-1133 (2009). doi:10.1890/07-2147.1

Acknowledgments: We thank all the researchers in Tylianakis lab for their insightful comments on this work.

Funding: University of Canterbury Doctoral Scholarship (LPM)

The Marsden Fund (grant number UOC1705) (JMT)

The São Paulo Research Foundation (BIOTA/FAPESP 2014/01986-0; 2015/15172-7, 2016/18355-8) (CE)

Brazilian Research Council (CNPQ) grants 540481/01-7 and 304742/2019-8 (MAP) 
Rufford Small Grants for Nature Conservation (No. 22426-1), Universidade Estadual de Santa Cruz (Propp-UESC; No. 00220.1100.1644/10-2018), and Fundação de Amparo a Pesquisa do Estado da Bahia (FAPESB; No. 0525/2016) (JCM, IM)

European Research Council under the European Union's Horizon 2020 research and innovation program (grant 787638) and the Swiss National Science Foundation (grant 173342), both awarded to C. Graham (DMD)

Deutsche Forschungsgemeinschaft, PAK 825/1 and FOR 2730 (KBG, ELN, MQ, VS, MS)

Portuguese Foundation for Science and Technology - FCT/MCTES contract CEECIND/00135/2017 and grant UID/BIA/04004/2020 (ST)

Portuguese Foundation for Science and Technology - FCT/MCTES contract CEECIND/02064/2017 (LPS)

National Scientific and Technical Research Council, PIP 592 (PGB)

\section{Author contributions:}

Conceptualization: LPM, JMT

Methodology: LPM, JMT, DBS

Investigation: LPM, JMT, DBS

Visualization: LPM, JMT

Funding acquisition: LPM, JMT

Project administration: JMT

Supervision: JMT, DBS

Writing - original draft: LPM, JMT 
Writing - review \& editing: All authors.

Competing interests: Authors declare that they have no competing interests.

Data and materials availability: The data and code used in this study will be available for download at dryad (34).

\section{Supplementary Materials}

Materials and Methods

Figs. S1 to S18

Tables S1 to S37

References (35-171) 


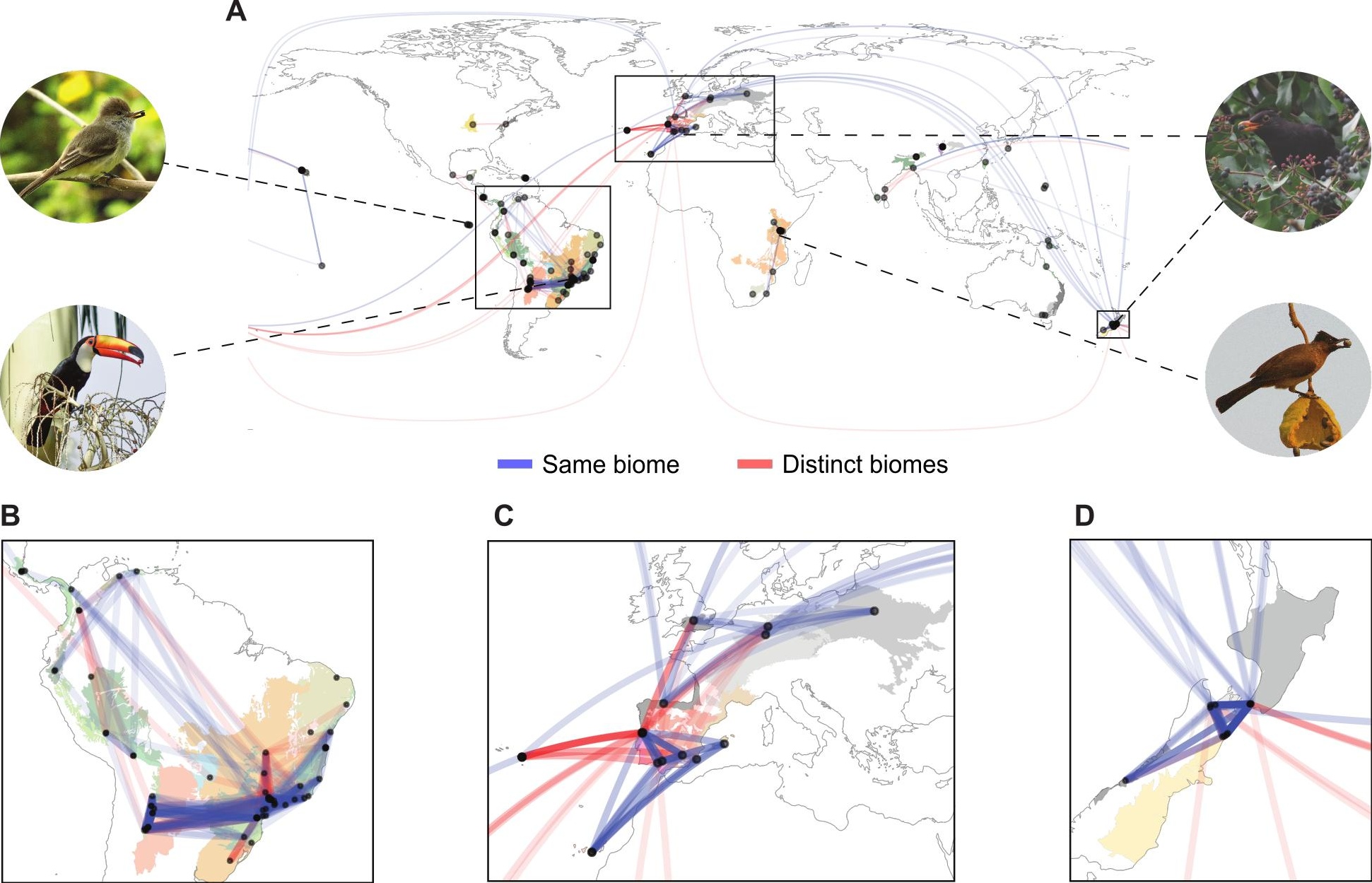




\section{Interaction dissimilarity}
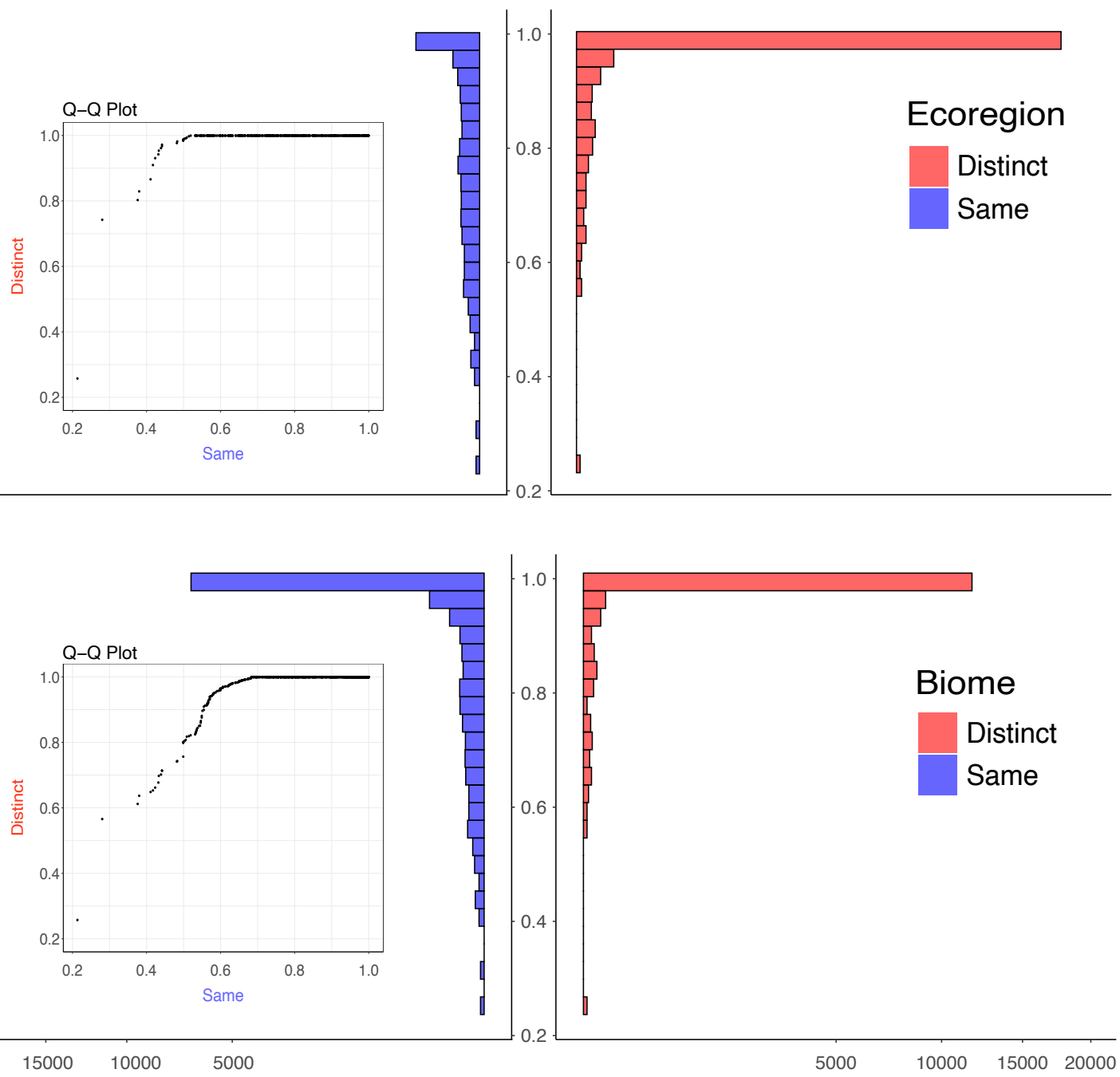

Frequency 
A

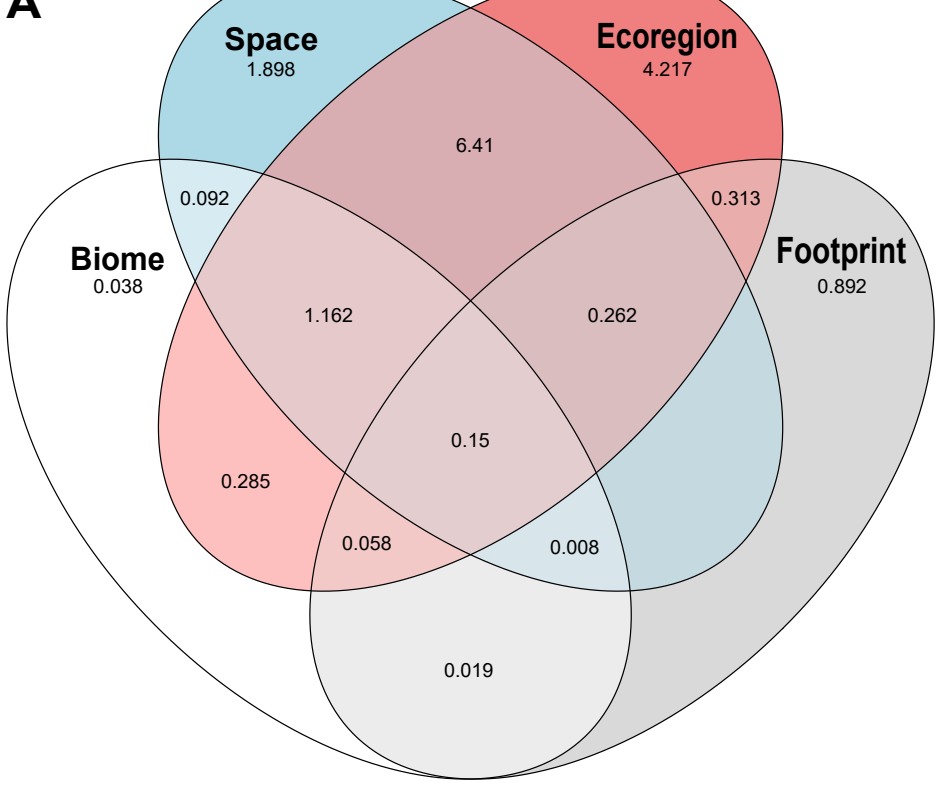

B

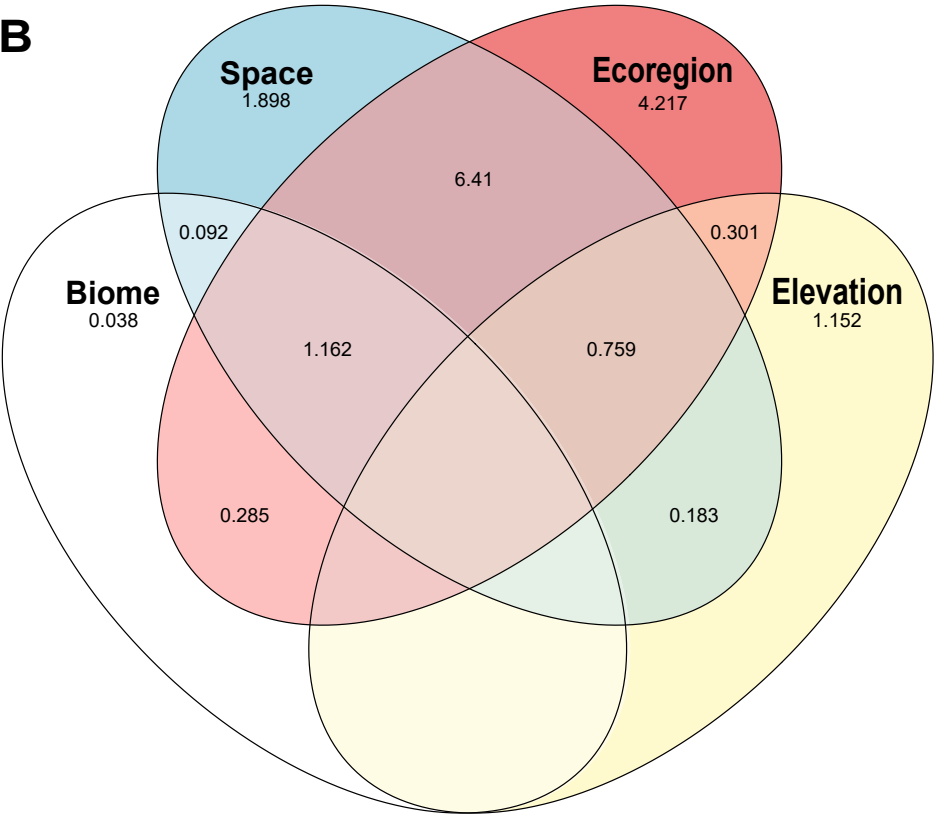




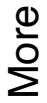
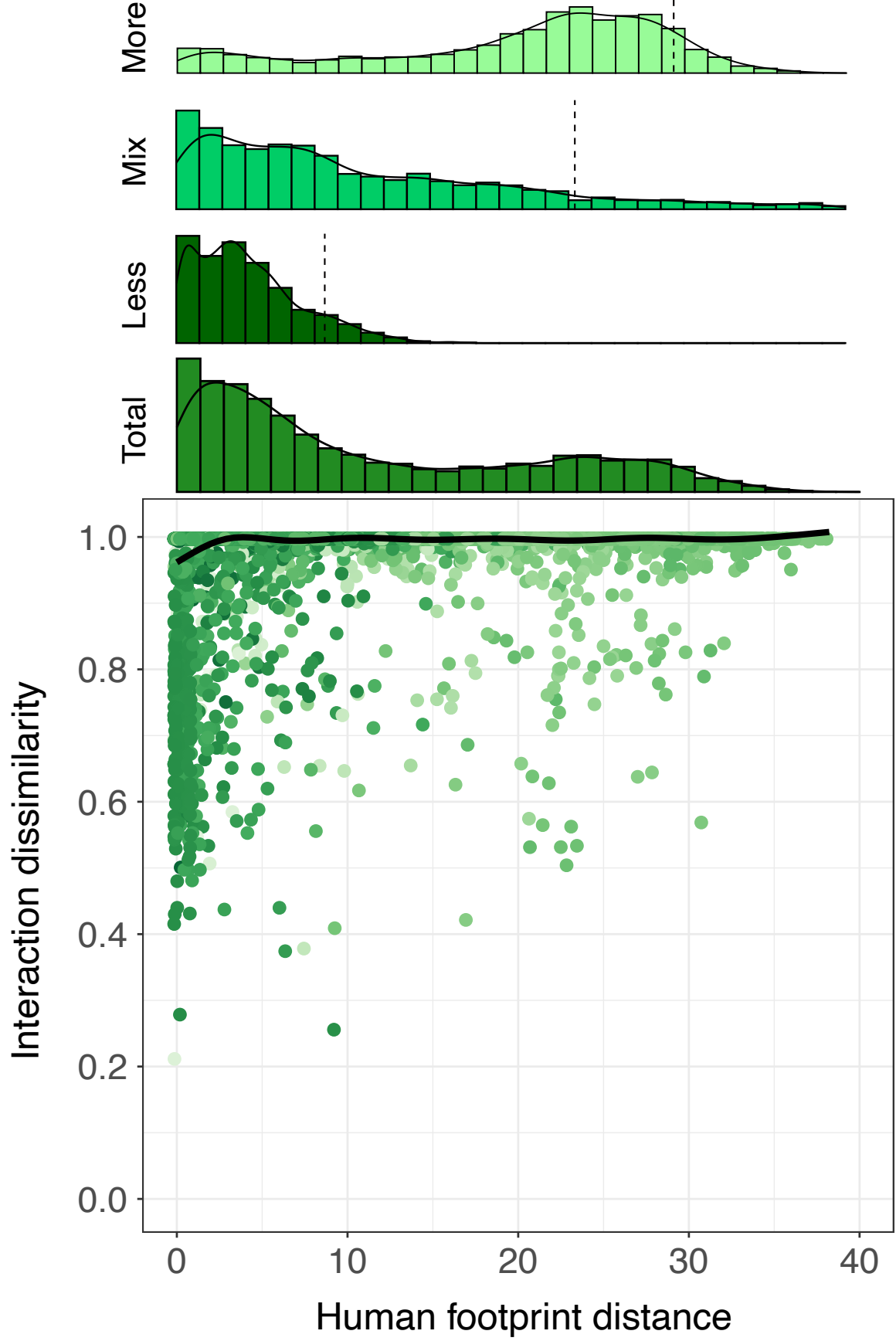

Mean Footprint 60 40 20 0 


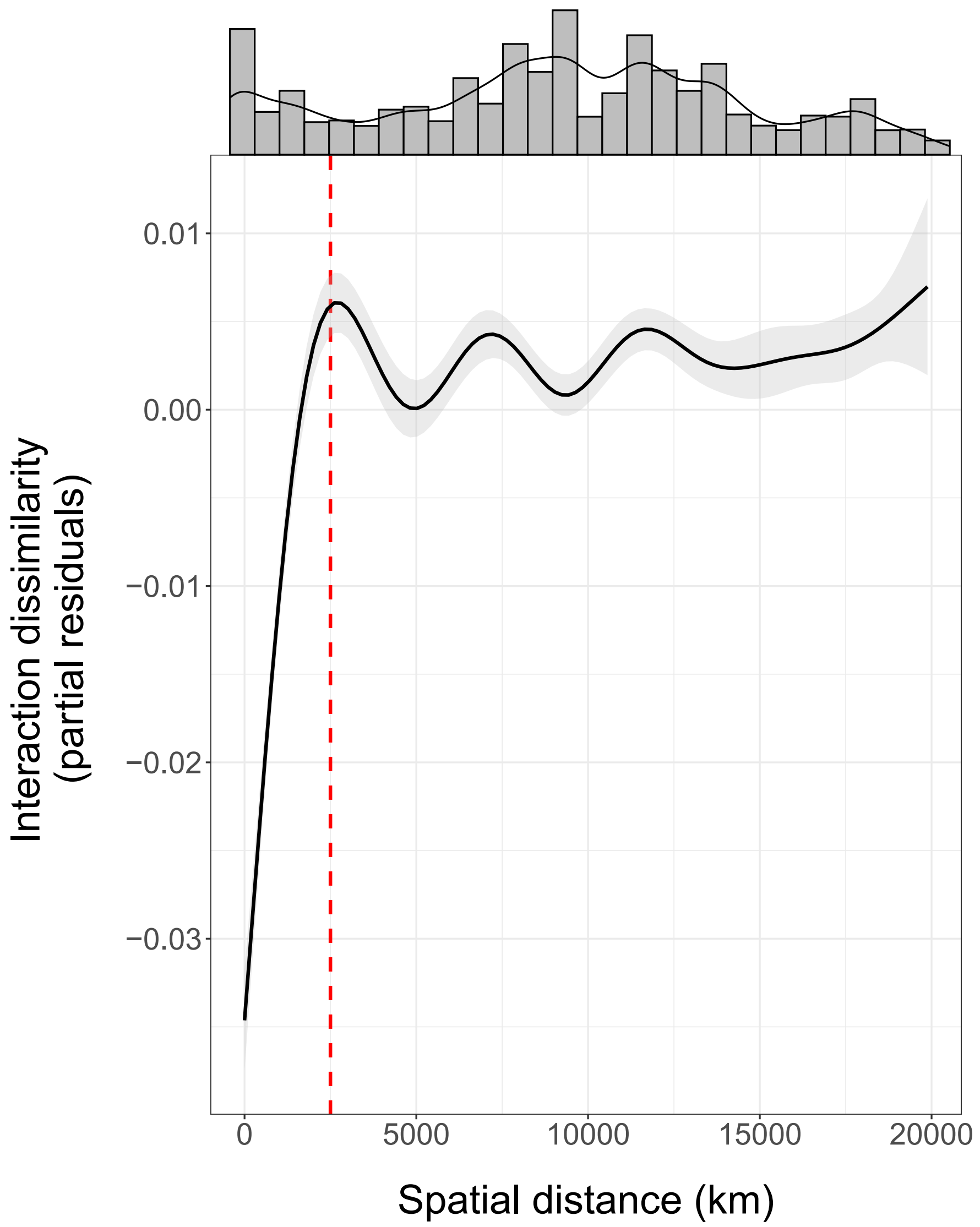

